\title{
Kamu Kurumlarının Kriz Yönetimi Becerileri: Samsun Büyükşehir Belediyesi Çalışanlarına Yönelik Bir Araştırma*
}

\author{
Caner Özarslan (Doktora Öğrencisi) \\ Atatürk Üniversitesi Sosyal Bilimler Enstitüsü \\ ozarslancaner@gmail.com \\ ORCID: 0000-0003-4345-470X \\ Ersin Diker (Dr. Öğr. Üyesi) \\ Gümüşhane Üniversitesi İletişim Fakültesi \\ ersindiker@gumushane.edu.tr \\ ORCID: 0000-0002-3973-0639
}

Başvuru Tarihi: 18.11.2019

Yayına Kabul Tarihi: 13.12.2019

Yayınlanma Tarihi: 24.01.2020

DOI: http://10.17680/erciyesiletisim.648215

\section{Öz}

$\mathrm{Bu}$ çalışmada, çalışanların tutumları göz önünde bulundurularak Samsun Büyükşehir Belediyesi'nin sahip olduğu kriz yönetim becerilerinin mevcut durumunun belirlenmesi amaçlanmıştır. Yapılan literatür taraması sonucunda Samsun Büyükşehir Belediyesi örnekleminde kriz yönetimi becerilerinin mevcut durumunu ortaya koyan herhangi bir çalışma bulunamamıștır. Bu yönü ile çalışmanın literatüre katkı sağlaması ve kurumların kriz yönetiminde uygulayacağı faaliyetlere yeni bir yaklaşım sunması beklenmektedir. Araştırmanın örneklemi belirlenirken basit tesadüfi örnekleme yöntemi tercih edilmiş ve 406 katılımcı ile araştırma gerçekleştirilmiştir. Sosyal bilimler alanında kabul gören nicel araștırma yöntemlerinden yüz yüze anket tekniği çalışmanın yöntemi için uygun görülmüş olup, doğrulayıcı faktör analizi, bağımsız iki örneklem t testi, Anova, korelasyon ve regresyon analizleri ile veriler incelenmiştir. Samsun Büyükșehir Belediyesinde görev alan 406 çalışan ise çalıșmanın örneklemini oluşturmaktadır. Bu doğrultuda kurum çalışanlarına geçerliği ve güvenirliği kanıtlanmış anket uygulaması 2018 yılının Kasım ayı içerisinde yapılmıştır. Anket uygulamasından elde edilen veriler analiz edilerek bulgular değerlendirilmiştir. Çalışma sonucunda kurumun çalışanlara karşı daha samimi olması, sürekli karşılıklı iletişimi sağlaması, kriz ve kriz yönetimi ile ilgili uygun eğitimler düzenlemesi gibi faaliyetlerde yetersiz olduğu anlaşılmıştır. Diğer taraftan kurumun kriz yönetim becerilerine ilişkin algı puanlarının katılımcıların cinsiyetine göre anlamlı farklılık sadece kriz dönemi ve kriz sonrası yönetim becerileri alt boyutlarında meydana gelmiştir. Çalışmanın bir diğer sonucuna göre, çalışanların eğitim seviyeleri yükseldikçe kurumdaki kriz durumuna ve kriz yönetim becerilerine olan ilgi ve farkındalığın artabileceği söylenebilir. Çalışmanın genel sonucuna bakıldığında kurumun mevcut kriz yönetim becerilerinin "orta düzeyde" bulunduğu ortaya çlkmiştır.

Anahtar Kelimeler: Kriz, Kriz Yönetimi, Kriz Yönetim Becerileri, Kamu Kurumu, Samsun Büyükşehir Belediyesi.

\footnotetext{
* Bu çalışma, Gümüşhane Üniversitesi Sosyal Bilimler Enstitüsü’ne 2019 yılında sunulan "Kamu Kurumlarının Kriz Yönetimi Becerileri: Samsun Büyükşehir Belediyesi Çalışanlarına Yönelik Bir Araştırma” başlıklı yüksek lisans tez özetidir.
} 
Dissertation

\title{
Crisis Management Skill of Public Institutions: A Survey on Employees of Samsun Metropolitan Municipality
}

\author{
Caner Özarslan (Ph.D. Student) \\ Atatürk University Institute of Social Sciences \\ ozarslancaner@gmail.com \\ ORCID: 0000-0003-4345-470X \\ Ersin Diker (Asst. Prof. Dr.) \\ Gümüşhane University Faculty of Communication \\ ersindiker@gumushane.edu.tr \\ ORCID: 0000-0002-3973-0639
}

Date Received: 18.11.2019

Date Accepted: 13.12.2019

Date Published: 24.01.2020

DOI: http://10.17680/erciyesiletisim.648215

\begin{abstract}
In this study, it is aimed to determine the current situation of crisis management skills of Samsun Metropolitan Municipality taking into consideration of manners of employees. As a result of the literature review, no study could be find which showed the current status of crisis management skills in the sample of Samsun Metropolitan Municipality. In this respect, the study is expected to contribute to the literature and provide a new approach to the activities that the institutions will implement in crisis management. Simple random sampling method was preferred when determining the sample of the study and the study was conducted with 406 participants. Face to face questionnaire technique, one of the qualitative research methods accepted in social sciences field, is chosen for study method and data are analysed in terms of confirmatory factor analysis, two unpaired t tests, Anova, correlation and regression analysis. 406 employees of Samsun Metropolitan Municipality constitute the sample of the study. Accordingly, in November 2018 a confidential poll has been conducted to employees of the institution. Findings have been evaluated by analysing data from the poll. It is discovered that the institution has been incapable of doing activities such as being more sincere to its employees, mutual communication and organize training programs about crisis management. On the other hand, perception points of participants related to crisis management skills differ according to gender and this difference occurs only in sub-dimensions of management skills of crisis period and post-crisis. According to another result of the study, it can be said that as the education level of employees increase, interest and awareness of crisis situation and crisis management skills in a institution may arise. Considering general outcome of the study, it is clear that the current crisis management skills of the institution are of "intermediate level".
\end{abstract}

Keywords: Crisis, Crisis Management, Crisis Management Skills, Public Institute, Samsun Metropolitan Municipality. 


\section{Giriş}

Günümüzde birçok faktörün günlük yaşama ve iş hayatına olumsuz etkileri bulunmaktadır. Ortaya çlkan bu olumsuz etkilerin, krizlerin oluşumuna neden olduğu söylenebilir. Özellikle geniş kitlelere yönelik faaliyette bulunan kurumlar, krizleri daha sık yaşamakta ve kriz sürecine daha fazla zaman ayırmaktadır. Dolayısıyla kurumlar, kriz sürecini etkin yöneterek hem potansiyel krizlerin sayısını azaltabilir hem de çözüm odaklı faaliyetler uygulayarak kısa sürede sonuca ulaşabilir.

Kurum yöneticilerinin krizlere karşı uyguladığı kriz yönetim becerileri sayesinde kurumlar, krizleri daha etkin bir şekilde yönetmektedir. Kurumların üst düzey yöneticilerinde bulunması gereken kriz yönetim becerileri, kriz süreçlerinde yönetimin aktif bir biçimde gerçekleşmesine yarar sağlamaktadır. Buradan hareketle kriz yönetim becerileri, kurumlar tarafından benimsenmesi gereken yönetimsel eylemler şeklinde açılklanabilir.

Kurumlarda her an meydana gelebilecek krizlerin etkin olarak yönetilmesinde yarar sağlayan kriz yönetim becerileri bu çalışmanın konusunu oluşturmaktadır. Bu çalışma Samsun Büyükşehir Belediyesi'nin sahip olduğu kriz yönetim becerilerinin mevcut durumunu belirlemeye yöneliktir. Literatür çerçevesinde çalışmada kriz kavramı ve tanımı, kriz yönetimi ve kriz yönetim becerileri genel hatlarıla kavramsal olarak anlatılmaktadır. Çalışmanın yöntem kısmında ise kurum çalışanlarının, kurumun kriz yönetim becerilerine yönelik tutumları belirlenerek Samsun Büyükşehir Belediyesi'nin kriz yönetimi becerilerinin mevcut durumu ile ilgili bulgular ele alınmaktadır. Katılımcıların kurumun kriz yönetim becerileri ile ilgili tutumları ve kriz yönetim becerilerine ilişkin algı puanlarının katılımcıların demografik özelliklerine göre anlamlı farklılık gösterip göstermediğini tespit etmek amacıyla analizler yapılmıştır. Ayrıca kriz yönetim becerilerine ait korelasyon ve regresyon analizlerine ilişkin sonuçlar da değerlendirilmeye alınmıştır.

\section{Kriz Kavramı}

Her yerde, her zaman, herkesin karşı karşıya kalabileceği kavram olan kriz, günlük yaşamın bir parçasıdır. Fakat beklenmeyen olaylarla baş başa kalınamayacağı düşüncesi, genel olarak her bireyde hâkim olmaktadır. Ayrıca bu durum bireylerde olduğu kadar kurumlarda da geçerlidir (Bakos, 2018, s. 527). 21. yüzyılın iş yaşamında meydana gelen krizler, kurumlar için önemli bir olgu haline dönüşmektedir. Günümüzde zorlu rekabet ortamında yaşamını sürdüren kurumların, kendi dışında oluşan olumsuz durumlar ya da benimsedikleri yönetim politikalarının sonucunda ortaya çıkan negatif olaylar nedeni ile tecrübe ettikleri krizlerin sayısı gün geçtikçe artmaktadır (Aydın ve Kılınç, 2004, s. 5). Dolayısıyla krizlere karşı gerekli önlemlerin alınması, kurumların geleceği açısından önem kazanmaktadır.

Dikkate alınması gereken bir unsur şeklinde ifade edilen kriz kavramının açıklığa kavuşturulması için yapılmış pek çok tanım literatürde yer almaktadır. Sosyal bilimler içerisinde bulunan diğer disiplinlerde görüldügü gibi kriz kavramında da genel bir tanım birliğinin olmadığı anlaşılmaktadır. Fakat kriz ile ilgili ortaya konulmuş tanımlara bakıldığında; krizin ciddi bir durum veya sorun ortamını oluşturduğu görüşü üzerinde bir fikir birliğinin sağlandığı görülmektedir. Kriz kelimesine etimolojik olarak bakıldığında Yunancada "ayrılmak" anlamını veren "krisis" sözcügüne dayanmaktadır. Çin yazısında kriz, "fırsat" ve "tehlike" şeklinde iki sembol ile ifade edilerek olumlu ve olumsuz anlamlarının olduğu dile getirilmektedir (Pira ve Sohodol, 2004, s. 23). Oxford 
sözlüğünde kriz, en iyinin olabileceği ya da en kötünün meydana gelebileceği bir dönüm noktası şeklinde yer almaktadır (Korkmazyürek ve Basım, 2009, s. 2-3). Türk Dil Kurumu'nun güncel Türkçe Sözlüğünde ise kriz, bunalım ortamında yer almak, buhran olarak belirtilmektedir (Türk Dil Kurumu, 2019).

Diğer bir tanıma göre kriz, kurumun gelişimi açısından önemli olan hedeflerini ve faaliyet sistemini tehdit altına alan, kurumun varlığına zarar veren, hızlı bir şekilde tepki gösterilmesi gereken, kurumun krize engel olma mekanizmalarından yararlanmasına firsat tanımayan olağanüstü bir durum biçiminde tanımlanmaktadır (Can, 2005, s. 387). Dinçer'e (2007, s. 407) göre kriz, öngörülemeyen ve beklenmedik bir anda oluşan, güncel değerlerini, hedeflerini ve vizyonunu tehlikeye atan, cevabın hızlıca verilmesini gerektiren bir olgu olarak belirtmektedir. Coombs'a (2015, s. 3) göre kriz, paydaşların sağlık, güvenlik, çevre ve ekonomik hususlar ile ilgili önemli beklentilerini tehlike altında bırakan ve kurumların verimliliklerini ciddi şekilde etkileyebilecek ve olumsuz durumlara yol açabilecek öngörülemeyen olaylardır. Bu çerçevede yapılan tanımlara bakıldığında kriz ortamının gerilim oluşturması sebebi ile kriz yönetiminin, kurumun geleceği açısından dikkate alınması gereken kavram olarak görülmesi gerekmektedir (Tekin ve Öztürk, 2010, s. 134).

\section{Kriz Yönetimi Kavramı}

Küreselleşme unsurunun getirdiği rekabet olgusunun artan etkisiyle birlikte, ulusal ve uluslararası piyasada yaşamını sürdüren kurumlar sürekli krizi tecrübe etmektedir. Krizin egemen olduğu kurumlarda belli başlı kararları alma güçlüğü, kaos ortamında faaliyet gösterme, finansal ve kurumsal zararlara uğrama gibi olumsuz durumlardan dolayı başarılı bir yönetime gerek duymaktadır (Akgemci, 2015, s. 484).

Can (2005, s. 397), kriz yönetimini kurum yöneticisinin olası tehlike anlarını, kurumun hedeflerini göz önünde bulundurarak düşük bütçe ile karşılama çabası olarak tanımlamaktadır. Başka bir ifadeyle kriz yönetimi, olası bir kriz ortamına karşı kriz sinyallerinin algılanarak yorumlanması, kurumun kriz sürecinin olabildiğince zararsız bir şekilde geçirmek için gerekli tedbirleri alması ve bu tedbirler ışığında yeterli faaliyetlerin gerçekleştirmesi şeklinde belirtilmektedir (Şimşek, 1998, s. 312).

Kriz yönetimi farklı aşamaları içerisinde barındırmaktadır. Kriz yönetim ekibi tarafından her aşamada faklı uygulamaların hayata geçirilmesi gerekmektedir. Örneğin herhangi bir krizin algılanması, krize karşı ilk müdahale anlamına gelmemektedir. İlk müdahale, kriz durumunun değerlendirilmesi ve uygun kriz stratejilerinin geliştirilmesidir. Son aşama olarak görülen kriz yönetiminin değerlendirmesi ise yeniden meydana gelecek krizlere karşı yapılacak olası faaliyetlerin belirlenmesi ve performans artırımının sağlanmasıdır (Coombs, 2001, s. 90). Bu nedenle kriz yönetiminin kriz anında gösterilen taktiksel çaba şeklinde açıklanması doğru bir ifade olmamaktadır. Dolayısıyla kriz yönetimi, kriz hazırlıkları, krize karşı yanıt ve kriz sonrası toparlanma sürecini kapsayan proaktif bir disiplindir (Jaques, 2007, s. 148).

Kurumları ciddi hasara uğratabilecek ve tehlike arz eden durumlara yönelik belli başlı hazırlıkları içeren kriz yönetimi, aşağıda yer alan özelliklere sahiptir (Büyükkaracığan, 2016, s. 202):

- Kriz yönetimi, birden fazla aşamadan oluşan ve özel bir yönetim biçimi olarak gösterilen yönetsel süreçtir. 
- Kriz yönetimi, uzun vadeli, döngüsel ve devamlılık anlayışını temel alan, etkileşimli ve karmaşık faaliyetleri içeren bir süreç şeklinde karşımıza çıkmaktadır.

- Kurum için tehlike arz eden durumlarla ilgilenen kriz yönetimi, bu durumların yaşanmasını önlemeyi ya da gerçekleşen durumların kuruma verebileceği hasarı en aza indirmeyi hedeflemektedir.

- Kriz yönetimi, muhtemel kriz belirtilerinin algılanmasına ve krizlere yönelik gerekli hazırlıkların yapılamasına katkı sağlamaktadır.

- Kriz yönetiminde kurumun üst düzey yöneticilerinin olumsuz durumu öngörme düzeyi, krizi engelleme açısından önem kazanmakta ve kaos ortamını yönetecek çalışanın ya da çalışanların, kriz hakkındaki deneyim ve tecrübeleri belirleyici olmaktadır.

- Devamlılığı temel alan kriz yönetimi, kriz sürecini bir bütün olarak ele almaktadır.

- Kurumun karşı karşıya kaldığı krizi kontrol altına almayı amaçlayan kriz yönetimi, olabildiğinde en az zararla kriz dönemini geçirmeyi hedeflemektedir.

- Kriz yönetimi, kurumun ve meydana gelen krizin çeşidine ve niteliklerine göre faaliyetlerini gerçekleştirmektedir.

- Kriz yönetimi, disiplinler arası yaklaşım biçimidir.

Krizin türü ne olursa olsun, etkisi altında kalan kurumun içinde olduğu ortam değişmemektedir. Böylesine bir durumda, her zaman geçerli olan cevaplar yetersiz kalmakta ve kurumda değişmeyi sağlayacak ve yeni çalışmaları oluşturacak yapı eksikliği ortaya çıkmaktadır. Hızlı karar alma mecburiyetinde olan kurum yönetimi, hedeflerin tanımlanmasında zorluklar yaşayabilir. Kurum yönetimi bu durumu nitel olarak karşılamakta, dolayısıyla kurumun nasıl bir yol izlediği hakkında bilgi sahibi olma ve değerlendirme olanağı bulunmamaktadır (Dinçer, 2007, s. 423). Bu çerçevede kriz dönemlerini zararsız bir şekilde geçirmek için kurumların olası krizlere göre senaryolar ve uygun planlamalar hazırlayarak, meydana gelebilecek sorunların krize dönüşmesini bu hazırlıklar sayesinde engelleyip sağlam adımların atılması sağlanabilir.

\section{Kurumların Kriz Yönetim Becerileri}

Kurumlar, kriz yönetimini bir disiplin olarak görmeleri gerekmektedir. Etkili kriz yönetiminin uygulanması kurumları hızlı bir şekilde eski haline getirdiği ve krizleri fırsata çevirerek faydalı sonuçlara ulaşmaya yardımcı olduğu söylenebilir (Patan, 2009, s. 36). Bu doğrultuda kurumu krizden kurtarmak ve krizi firsata çevirmek için yöneticilerde kriz yönetimi becerilerinin bulunması gerekmektedir. Özellikle kriz durumlarında gerekli kriz yönetim becerilerine sahip olan yöneticiler, hem kurumun varlığını devam ettirmelerini hem de meydana gelen firsatları değerlendirme imkanına sahip olmaktadırlar (Sezgin, 2012, s. 35). Buradan hareketle kurumların üst düzey yöneticilerinde bulunması gereken önemli kriz yönetimi becerileri șu şekilde belirtilebilir (Kotwica ve Hayes, 2013, s. 20):

Sakin kalmak: Kriz yönetimi açık düşünme, duygusal kontrol ve denge gerektirir.

Açık fikirli olmak: Olabildiğince fazla bilgi edinip sürekli dinleyici konumunda bulunmak kriz yönetimi becerilerinin önemli hususlarından biridir.

Kararlı olmak: Karar vericinin kendi fikirleri ve başkalarından elde edilen veriler göz önünde bulundurularak karar belirlenmelidir. Sadece kısmi bilgiye öncelik vererek karara varmak burada önem kazanmaktadır.

Esnek olmak: Kritik olaylar hakkında aktarılan bazı bilgilerin yanlış veya eksik olduğunu unutmadan hızla değişen durumlara uyum sağlamak bir diğer kriz yönetimi becerisidir. 
Íkna edici olmak: Kriz yönetimi, kurum çalışanlarına oluşturulan yönergeleri izlemeye ikna etmeyi gerektirir.

Kriz yönetimi becerilerinde ön planlama, eğitim ve öğrenme krize etkili bir şekilde yanıt verme konusunda yardımcı olmaktadır. Kurumların yüzleşeceği olayların tahmin edilmesi zor görünse de krize nasıl tepki verileceği ve krizin değișimini öngörebilmek için nelerin yapılacağı konusunda çoğu bilgiye ulaşılabilir. Böylesine durumlar çok sayıda insanın olduğu ve krizin bir endișe kaynağına neden olacağı kuruluş, okul, hastane, gibi ortamlarda önem kazanmaktadır (Wynne, 2009, s. 61). Dolayısıyla kurumların kriz yönetimi becerilerinin gelişiminde öğrenme kavramı büyük öneme sahiptir. Kriz yönetiminin iyileştirilmesi adına kurum ve kurum çalışanları, öğrenmeyi bir kurumsal öğe haline getirip çalışmalarını bu doğrultuda yapmaları daha doğru bir yaklaşım olabilir (Bernhardsdóttir, 2015, s. 111). Buradan hareketle yapılacak ön planlamanın, eğitim ve öğrenme ile doğrudan bir ilişkisinin bulunduğu söylenebilir.

Meydana gelen değișimlere ayak uydurabilen kurumlar krizin olumsuz etkilerinden korunabilir. Fakat kurumların ortaya çıkan bu değişimleri benimsemesi her daim mümkün olmamaktadır. Çalışmaların niteliği, yararlanılan teknoloji, bütçenin yetersiz oluşu, kurum yönetimin deneyimsizliği ya da yeni pazarlarda yer edinme olasılığının bulunmaması kurumları kötü durumlara sürükleyebilir (Özdevecioğlu, 2002, s. 95). Bu tür olumsuz olayların yanında kurumlar, yönetimsel bunalımlar da yaşamaktadırlar. Yaşanan her yönetim bunalımında insan unsurunun etkisi bulunmaktadır. Kurum yöneticisi oluşan bu bunalımı çözüme kavuşturmalı, ilgili bireylerde meydana gelen manevi ya da maddi zararları onarmalı ve mümkün olduğunca aynı durumların tekrar yaşanmaması için önlemler almalıdır (Demirtaş, 2000, s. 364).

\section{Metodoloji}

Kamu kurumlarının kriz yönetimi becerilerini inceleyen bu çalışmada Samsun Büyükşehir Belediyesi çalışanlarına yönelik bir araştırma yapılmıştır. Kurum çalışanlarına uygulanmış anket formu ile hizmet verdikleri kurumun kriz yönetimi becerileri hakkındaki tutumları incelenmektedir.

\subsection{Araştırmanın Amacı ve Önemi}

Çalışmanın amacı, Samsun Büyükşehir Belediyesi'nin sahip olduğu kriz yönetimi becerilerinin ne düzeyde olduğunun belirlenmesi olarak ifade edilebilir. $\mathrm{Bu}$ amaç doğrultusunda örneklem olarak seçilen kuruma uygulanan anket çalışması ile kurumun kriz yönetimi becerilerinin ne düzeyde olduğu ortaya konulmaktadır. Araştırmanın önemi ise hem bu alandaki literatüre bir katkı hem de kurumların kriz yönetiminde uygulayacağı faaliyetlere yeni bir yaklaşım sunması olarak ifade edilebilir. Çalışma, kurumların bu araştırmayı göz önünde bulundurarak kriz öncesi, anı ve sonrası dönemlerde gerçekleștirecekleri kriz yönetimi faaliyetlerine fayda sağlayabilir. Ayrıca Samsun Büyükşehir Belediyesi örnekleminde kriz yönetimi becerilerinin mevcut durumunu ortaya koyan herhangi bir çalışmaya ulaşılamamıştır. Bu yönü ile literatüre ve yapılacak yeni araştırmalara katkıda bulunması beklenmektedir.

\subsection{Araştırmanın Sınırlııkları}

Araştırmanın sınırlıkları aşağıda belirlenmiştir:

- Bu araştırma Kasım 2018 tarihinde gerçekleştirildiğinden dolayı zamanı ele alış bağlamında kesitsel bir araştırmadır. 
- Samsun Büyükşehir Belediyesi çalışanlarının hepsine ulaşmak zaman kısıtı ve maliyet zorluğundan dolayı araştırma, 406 katılımcı ile gerçekleștirilmiştir. Ancak bazı anketlerin yanlış veya eksik cevaplanması nedeniyle 30 anket geçersiz kabul edilip 376 anket analiz edilmiştir.

- Araştırmanın bulguları, nicel araștırma yönteminin yüz yüze anket tekniği özellikleri ile sinirlidir.

- Araştırma sadece Samsun Büyükşehir Belediyesi örnekleminde ve Samsun ilinin Çarşamba, Terme ve merkez ilçelerinde sınırlandırılmıştır.

\subsection{Araştırmanın Yöntemi}

Konu ve olayların objektif bakış açısı ile dışarıdan ölçümlenerek veya gözlemlenerek, tasvir etmeyi ya da sebep sonuç ilişkisi ile gerçeklere ulaşmayı amaç edinen araştırmalar nicel araştırma olarak adlandırılmaktadır (Arıkan, 2013, s. 27). Çoğunlukla nicel araștırmalarda kullanılan bir yöntem olan anket tekniği, çalıșma kapsamında incelenen kişi, grup veya örgütlerden elde edilecek verilere basitleștirilmiş ifadelerle ulaşmayı mümkün kılan veri toplama aracıdır (Ural ve Kılıç, 2006, s. 55). Bu bağlamda kurumun kriz yönetimi ve kriz yönetim becerileri hakkındaki bilgilere, kurum çalışanlarının bu konu ile ilgili düşünce ve tutumları göz önünde bulundurularak ulaşılabilir. Dolayısıyla çalışmada, sosyal bilimler alanında kabul gören nicel araştırma yönteminden yüz yüze anket tekniği kullanılmıştır.

\subsection{Araştırmanın Evreni ve Örneklemi}

Samsun Büyükşehir Belediyesi'nde Kasım 2018 tarihi itibariyle 2713 çalıșan görev almaktadır. Bu sayı belediyede görevini sürdüren yetkili personel vasıtasıyla belirlenmiștir. $\mathrm{Bu}$ doğrultuda belediyenin sahip olduğu kriz yönetimi becerilerinin mevcut durumunu ortaya koyan araștırmanın evrenini, kurumda görev alan 2713 çalışan oluşturmaktadır. Toplam çalışan sayısına göre örneklem sayısı belirlenmiştir.

Araştırmanın örneklemi belirlenirken "basit tesadüfi örnekleme yöntemi" tercih edilmiştir. Bu örneklem yöntemine göre araștırmanın örneklemini Kasım 2018 tarihi itibariyle Samsun Büyükşehir Belediyesinde görev alan 406 çalışan oluşturmaktadır. Tesadüfi örnekleme yöntemleri arasında yer alan basit tesadüfi örnekleme yöntemi, bilimsel araştırmalarda yaygın olarak kullanılmaktadır. Basit tesadüfi örnekleme yönetimi, ana kütleyi temsil edebilecek bir örnek büyüklügünün belirlenip, bu sayıya ulaşana kadar örnek kütlenin tesadüfü olarak seçilmesi şeklinde tanımlanabilir (Küçük, 2014, s. 87). Bu doğrultuda araştırmanın örneklem sayısı, evrenin toplam sayısına göre oluşturulmuștur. Basit tesadüfi örneklem yöntemi esas alınıp oluşturulan örneklem sayısına ulaşana dek, kurum çalışanlarına anket uygulaması yapılmıştır. Belirlenen örneklem sayısı dahilinde 406 kurum çalışanı gönüllülük esası çerçevesinde anket uygulamasına katılmıştır. Yapılan 406 anketin 30'u belirli nedenler sonucunda geçersiz kabul edilip 376 anket araştırmaya tabi tutulmuştur.

Anket uygulaması yapılmadan önce kurum personeline ön test çalışması yapılmıştır. Gerçekleştirilen ön test çalışmasına toplam 51 kurum çalışanı katılmıştır. Yapılan bu çalışma sonucunda anket formunun anlaşılmayan kısımları düzeltilmiş ve anket formu yeniden tasarlanmıştır. Ayrıca ön test sonrasında ankette 6 adet tuzak soru oluşturularak kurum çalışanlarının ankete sağladıkları katılımın ne düzeyde olduğu anlaşılmaya çalışılmıştır. Bu tuzak sorular için veri girişi esnasında ters kodlama yapılmıștır. 


\subsection{Araştırmanın Hipotezleri}

Samsun Büyükşehir Belediyesi'nin gösterdiği kriz yönetimi becerilerinin mevcut durumunu sorgulayan çalışmada, kurum çalışanlarının tutum ve düşünceleri ele alınmaktadır. Bu doğrultuda oluşturulan araștırmanın hipotezleri aşağıdaki gibidir:

- $\mathrm{H} 1_{\mathrm{A}}$ : Katılımcıların çalıştıkları kurumdaki kriz öncesi yönetim becerilerine yönelik tutumları cinsiyet değişkenine göre anlamlı farklılık gösterir.

- $\mathrm{H} 1_{\mathrm{B}}$ : Katılımcıların çalıștıkları kurumdaki kriz anı yönetim becerilerine yönelik tutumları cinsiyet değişkenine göre anlamlı farklılık gösterir.

- $\mathrm{H} 1_{C}$ : Katılımcıların çalıștıkları kurumdaki kriz sonrası yönetim becerilerine yönelik tutumları cinsiyet değişkenine göre anlamlı farklılık gösterir.

- $\mathrm{H}_{\mathrm{A}}$ : Katılımcıların çalıştıkları kurumdaki kriz öncesi yönetim becerilerine yönelik tutumları yaş değişkenine göre anlamlı farklılık gösterir.

- $\mathrm{H}_{\mathrm{B}}$ : Katılımcıların çalıştıkları kurumdaki kriz anı yönetim becerilerine yönelik tutumları yaş değişkenine göre anlamlı farklılık gösterir.

- $\mathrm{H}_{\mathrm{C}}$ : Katılımcıların çalıştıkları kurumdaki kriz sonrası yönetim becerilerine yönelik tutumları yaş değişkenine göre anlamlı farklılık gösterir.

- H3 $3_{\mathrm{A}}$ : Katılımcıların çalıştıkları kurumdaki kriz öncesi yönetim becerilerine yönelik tutumları eğitim durumu değişkenine göre anlamlı farklılık gösterir.

- $\mathrm{H}_{\mathrm{B}}$ : Katılımcıların çalıştıkları kurumdaki kriz anı yönetim becerilerine yönelik tutumları eğitim durumu değișkenine göre anlamlı farklılık gösterir.

- H3 $3_{C}$ : Katılımcıların çalıștıkları kurumdaki kriz sonrası yönetim becerilerine yönelik tutumları eğitim durumu değişkenine göre anlamlı farklılık gösterir.

- $\mathrm{H}_{\mathrm{A}}$ : Katılımcıların çalıştıkları kurumdaki kriz öncesi yönetim becerilerine yönelik tutumları aylık gelir değiş̧enine göre anlamlı farklılık gösterir.

- $\mathrm{H} 4_{\mathrm{B}}$ : Katılımcıların çalıștıkları kurumdaki kriz anı yönetim becerilerine yönelik tutumları aylık gelir değişkenine göre anlamlı farklılık gösterir.

- H4 $4_{C}$ : Katılımcıların çalıștıkları kurumdaki kriz sonrası yönetim becerilerine yönelik tutumları aylık gelir değişkenine göre anlamlı farklılık gösterir.

- H5 $5_{\mathrm{A}}$ : Katılımcıların çalıştıkları kurumdaki kriz öncesi yönetim becerilerine yönelik tutumları çalıştığı pozisyon değişkenine göre anlamlı farklılık gösterir.

- H5 $_{B}$ : Katılımcıların çalıștıkları kurumdaki kriz anı yönetim becerilerine yönelik tutumları çalıștığı pozisyon değişkenine göre anlamlı farklılık gösterir.

- H5: Katılımcıların çalıștıkları kurumdaki kriz sonrası yönetim becerilerine yönelik tutumları çalıştığı pozisyon değişkenine göre anlamlı farklılık gösterir.

- H6 : Katılımcıların çalıştıkları kurumdaki kriz öncesi yönetim becerilerine yönelik tutumları çalıştığı yıl değişkenine göre anlamlı farklılık gösterir.

- $\mathrm{H6}_{\mathrm{B}}$ : Katılımcıların çalıștıkları kurumdaki kriz anı yönetim becerilerine yönelik tutumları çalıştığı yıl değişkenine göre anlamlı farklılık gösterir.

- H6: Katılımcıların çalıștıkları kurumdaki kriz sonrası yönetim becerilerine yönelik tutumları çalıştığı yıl değişkenine göre anlamlı farklılık gösterir.

- H7: Katılımcıların çalıștıkları kurumdaki kriz yönetim becerilerine yönelik tutumları arasında anlamlı bir ilişki vardır.

- H8 $8_{\mathrm{A}}$ Kriz öncesi yönetim becerileri kriz dönemi yönetim becerilerini doğrudan ve anlamlı bir şekilde etkilemektedir. 
- $\mathrm{H}_{\mathrm{B}}$ : Kriz öncesi ve kriz dönemi yönetim becerileri kriz sonrası yönetim becerilerini doğrudan ve anlamlı bir şekilde etkilemektedir.

\subsection{Verilerin Analizi ve Bulguların Değerlendirilmesi}

\subsubsection{Araştırmanın Güvenirlik Analizi}

Güvenirlik analizi, veri elde etmek amacıyla geliştirilen ölçekte bulunan ifadelerin (madde, önerme, soru vb.) kendi aralarında tutarlı olup olmadığını ortaya koymak amacıyla kullanılmaktadır. Başka bir ifadeyle katılımcıların ankette yer alan ifadelere vermiş oldukları cevaplar göz önünde bulundurularak bu ifadelerin tümünün aynı konuyu ölçüp ölçmediğini test eden analiz türüdür. Yapılacak güvenirlik analizi sonucunda ortaya çıkan güvenirlik katsayısı, "0 ile 1" arasında bir değer alması gerekmektedir. Araştırmanın güvenilirlik analizi için değer 1'e yaklaştıkça araştırmada kullanılan ölçeğin güvenirliği artmaktadır (Ural ve Kılıç, 2006, s. 286).

Tablo 1: Araştırmanın Güvenirlik Analizi

\begin{tabular}{|c|c|}
\hline Cronbach's Alpha & N of Items \\
\hline 0,946 & 30 \\
\hline
\end{tabular}

Tablo 1'de görüldüğü üzere araștırmanın Cronbach's Alpha katsayısı 0,946 olarak karşımıza çıkmaktadır. Cronbach's Alpha katsayısının "0,80 $\leq \alpha<1,00$ " aralığında bulunduğu görülmektedir. Buradan hareketle araştırmanın güvenirlik durumunun yüksek derecede olduğu anlaşılmaktadır.

\subsubsection{Veri Toplama Aracı}

Araştırmada veri toplama aracı olarak iki bölümden oluşan anket formu kullanılmıştır. Anket formunun ilk bölümünde Aksu ve Deveci (2009) tarafından ilköğretim okulu müdürlerinin kriz yönetim becerilerini ölçmek amacıyla geliştirilen ve bu çalışma kapsamında büyükșehir belediyesi için uygunluğu doğrulanacak olan "Kriz Yönetim Becerileri Ölçeği” yer almaktadır. Ölçekte yer alan ifadeler araştırma örneklemine uygun şekilde düzenlendiğinden yeniden detaylı güvenirlik ve geçerlik çalışmalarına ihtiyaç duyulmuştur. Ölçek beşli likert tipinde (1 - kesinlikle katılmıyorum, 2 - katılmıyorum, 3 - kararsızım, 4 - katılıyorum, 5 - kesinlikle katılıyorum) 30 madde ve 3 boyuttan (kriz öncesi, kriz dönemi ve kriz sonrası yönetim becerileri) oluşmaktadır. Aksu ve Deveci (2009) tarafından geliştirilen "Kriz Yönetim Becerileri Ölçeği", 31 maddeden oluşmaktadır. Bu ölçekte yer alan 12. madde araştırmanın konusuna uygun bulunmadığı için anket formundan çıkartılmıştır. Anket formunun ikinci bölümünde ise katılımcıların cinsiyet, yaş, öğrenim düzeyi, aylık gelir durumu, kurumdaki pozisyon ve kurumdaki çalışma süresi sorularından oluşan demografik bilgi bölümü bulunmaktadır.

Ölçekte ve alt boyutlarda yüksek puan kriz yönetimine ilișkin kriz öncesi, kriz dönemi ve kriz sonrası yönetim becerilerinin yüksek olduğunu ifade etmektedir. Ölçekteki madde boyut ilişkisi Tablo 2'de gösterilmiştir.

Tablo 2: Kriz Yönetimi Becerileri Ölçeği Madde Boyut İlişkisi

\begin{tabular}{|c|c|c|}
\hline Madde ve Boyut & & SS \\
\hline \multicolumn{3}{|l|}{ Kriz Öncesi Yönetim Becerileri } \\
\hline $\begin{array}{l}\text { 1. Kurum, kriz ortaya çıkmadan önce farklı kaynaklardan } \\
\text { gelen kriz sinyallerini algılayabilmektedir. }\end{array}$ & 3,13 & 1,15 \\
\hline 2. Kriz yaşanmadan önce kriz senaryoları oluşturulmaktadır. & 3,10 & 1,24 \\
\hline 3. Kurum için tehlike yaratabilecek sorunlar önceden saptanmaktadır. & 3,26 & 1,09 \\
\hline 4. Kurum çevrede meydana gelen krizleri takip etmektedir. & 3,24 & 1,14 \\
\hline
\end{tabular}




\begin{tabular}{|c|c|c|}
\hline Madde ve Boyut & & SS \\
\hline \multicolumn{3}{|l|}{ Kriz Öncesi Yönetim Becerileri } \\
\hline 5. Krize neden olabilecek her durum dikkatle incelenmektedir. & 3,25 & 1,07 \\
\hline 6. Kurum kriz işaretlerine karşı duyarlıdır. & 3,35 & 1,11 \\
\hline $\begin{array}{l}\text { 7. Kurumda krizin olumsuz etkilerinden korunma stratejileri } \\
\text { konusunda bilgiye sahip çalışanlar mevcuttur. }\end{array}$ & 3,14 & 1,05 \\
\hline \multicolumn{3}{|l|}{ Kriz Dönemi Yönetim Becerileri } \\
\hline 8. Krizden korunmak için yazılı kriz yönetim planı hazırlanmaktadır. & 3,11 & 1,04 \\
\hline 9. Kriz yönetim planı çerçevesinde kriz iletişim planı hazırlanmaktadır. & 3,03 & 0,99 \\
\hline 10. Kriz döneminde uygulanacak acil eylem planı hazırlanmaktadır. & 3,28 & 1,08 \\
\hline 11. Kurum, kriz yönetim ekibinin gerekli eğitimi almasına öncülük etmektedir. & 3,03 & 1,07 \\
\hline 12. Kurum, tüm çalışanları kriz yönetim planından haberdar etmektedir. & 2,87 & 1,15 \\
\hline 13. Kurum çalışanlarına yaşanılan kriz hakkında kesinleşmiş bilgiler verilmektedir. & 2,82 & 1,12 \\
\hline 14. Kurumda tüm çalışanları kapsayacak kriz yönetimi hakkında eğitimler düzenlenmektedir. & 2,97 & 1,20 \\
\hline \multicolumn{3}{|l|}{ Kriz Sonrası Yönetim Becerileri } \\
\hline 15. Kriz yönetimi sürecinde kurum çalışanları arasında işbirliği sağlanmaktadır. & 3,09 & 1,09 \\
\hline 16. Çalışanların karar verme sürecine katılmalarını sağlanmaktadır. & 2,88 & 1,12 \\
\hline 17. Kriz yönetim sürecinde verimli çalışmayı önleyen engeller ortadan kaldırılmaktadır. & 2,99 & 1,08 \\
\hline 18. Kurumun amaç ve hedefleri sürekli gözden geçirilmektedir. & 3,24 & 1,05 \\
\hline 19. Kurum, kriz süreciyle ilgili çok yönlü değerlendirme yapmaktadır. & 3,10 & 1,10 \\
\hline 20. Kriz sonrası kurumda durum analizi yapılmaktadır. & 3,27 & 1,10 \\
\hline 21. Kriz sonrası kurumda yeni hedefler belirlenmektedir. & 3,22 & 1,02 \\
\hline 22. Kurum, gerçekleştirilen kriz yönetimini değerlendirmekte ve eksiklikleri belirlemektedir. & 3,26 & 1,02 \\
\hline 23. Kurum, kriz sonrası yeni bir yapılanma çalışması yapmaktadır. & 3,22 & 1,03 \\
\hline 24. Kriz sonrası kurumun vizyonu geliştirilmektedir. & 3,10 & 1,12 \\
\hline 25. Kriz sonrasında kurum güçlü ve zayıf yanlarını görmektedir. & 3,28 & 1,07 \\
\hline 26. Krizle mücadelede etkin yöntemler geliştirilmektedir. & 3,14 & 1,04 \\
\hline 27. Yaşanan krizler fırsata dönüştürülerek kurum için yararlı hale getirilmektedir. & 2,95 & 1,08 \\
\hline 28. Kriz yönetim ekibinin yeni gelişmelere uygun olarak eğitilmesine olanak sağlanmaktadır. & 3,11 & 1,12 \\
\hline 29. Olası krizle başa çıkabilmek için yeni strateji ve taktikler belirlenmektedir. & 3,14 & 1,07 \\
\hline 30. Çalışanlara yeni beceriler geliştirme ve bunları kullanma fırsatı verilmektedir. & 2,93 & 1,16 \\
\hline
\end{tabular}

Kriz yönetimi becerileri madde boyut ilişkisi tablosunda Tablo 2'de yer alan Kriz Öncesi Yönetim Becerileri alt boyutu, kurumların kriz öncesinde yaptığı çalışmaları kapsamaktadır. Bu alt boyutta bulunan maddeler arasındaki "kurum kriz işaretlerine karşı duyarlıdır" maddesine katılımcıların en yüksek değeri verdiği görülürken, "kriz yaşanmadan önce kriz senaryoları oluşturulmaktadır" maddesine ise en düşük değeri verdikleri ifade edilebilir. Diğer bir alt boyut olan Kriz Dönemi Yönetim Becerileri alt boyutu, kurumların kriz anında uyguladığı faaliyetleri içermektedir. $\mathrm{Bu}$ alt boyuttaki maddelere bakıldığında "kriz döneminde uygulanacak acil eylem planı hazırlanmaktadır" maddesi katılımcılar tarafından verilen en yüksek değer olarak belirtilirken, "kurum çalışanlarına yaşanılan kriz hakkında kesinleşmiş bilgiler verilmektedir" maddesi verilen en düşük değer şeklinde açıklanabilir. Son alt boyut olan Kriz Sonrası Yönetim Becerileri alt boyutu, kurumların kriz sonrası süreçte uygulayacağı çalışmalardan oluşmaktadır. Yine bu alt boyutta bulunan maddeler arasında katılımcıların en yüksek değerde gördügü "kriz sonrasında kurum güçlü ve zayıf yanlarını görmektedir" maddesi karşımıza çıkarken, "çalışanların karar verme sürecine katılmalarını sağlanmaktadır" maddesi ise katılımcılar tarafından en düşük değerde görülmüştür. 


\subsubsection{Verilerin Analizi}

$\mathrm{Bu}$ çalışmada ölçeğin geçerlik çalışmaları kapsamında doğrulayıcı faktör analizi ve güvenirlik çalışması için madde analizi (madde toplam korelasyonu ve Cronbach Alpha) yöntemleri kullanılmıștır. Doğrulayıcı faktör analizi (DFA), ölçme modellerinin oluşturulmasında sıkça tercih edilen ve aynı zamanda kolaylık da sağlayan analiz yöntemidir. DFA, geçmişte oluşturulmuş bir model aracılığı ile gözlenen değişkenler ön planda tutularak gizil değişkenin meydana gelmesini sağlayan bir işlemi içinde barındırmaktadır (Yaşlıoğlu, 2017, s. 78).

Yapısal eşitlik modellerinde model uyumu oluşturulurken uyum indeksleri yaygın olarak kullanılmaktadır. Model uyum indeksleri için belirlenen katsayılar Tablo 3'te yer almaktadır.

Tablo 3: Model Uyum Índeksleri

\begin{tabular}{|l|l|l|}
\hline Uyum Indeksleri & Kabul Edilebilir & Referans \\
\hline X2/sd & $<5$ & Tabachnick and Fidell, 2001 \\
\hline RMSEA & $\leq 0,07$ & Kollaway, 1989; Tabachnick and Fidell, 2001 \\
\hline SRMR & $\leq 0,08$ & Hu and Bentler, 1999; Brown, 2006 \\
\hline GFI & $\geq 0,90$ & $\begin{array}{l}\text { Kelloway, 1989; Schumacker and Lomax, 1996; Sümer, } \\
\text { 2000; Hooper, Coughlan and Mullen, 2008 }\end{array}$ \\
\hline NNFI & $\geq 0,90$ & $\begin{array}{l}\text { Kelloway, 1989; Schumacker and Lomax, 1996; Sümer, } \\
\text { 2000; Tabachnick and Fidell, 2001 Thompson, 2004 }\end{array}$ \\
\hline CFI & $\geq 0,90$ & Hu and Bentler, 1999; Sümer, 2000; Thompson, 2004 \\
\hline
\end{tabular}

Kaynak: Çokluk, Ö., Şekercioğlu, G. ve Büyüköztürk, Ş. (2012). Sosyal Bilimler Için Çok Değişkenli Istatistik: SPSS ve LISREL Uygulamaları. (2. Bs.). Ankara: PEGEM Akademi.

Madde analizi yöntemlerinden Cronbach Alpha tekniği, test puanları arasında bulunan iç tutarlığı belirlemek için kullanılmaktadır. Madde analizi yönteminin bir diğer tekniği olan madde-toplam korelasyonu, test maddelerinin ortaya koyduğu puanlar ile testteki toplam puanın arasındaki ilişkiyi açıklamaktadır. Madde-toplam korelasyonunun pozitif ve yüksek seviyede bulunmasının sonucunda maddelerin benzer davranışları örneklediği belirtilebilir. Aynı zamanda bu durum, testin iç tutarlığının yüksek düzeyde olduğunu göstermektedir. Genelde madde-toplam korelasyonu, 0,30 ve daha yüksek seviyede olan maddelerin bireyleri iyi derecede ayırt ettiği, 0,20 - 0,30 arasında bulunan maddelerin ise gerektiğinde tekrar teste tabi tutulabileceği söylenebilir. Cronbach Alpha tekniği, iç tutarlığı göstermekte olup genellikle 0,70'in üzerinde olması gerekmektedir (Büyüköztürk, 2018, s. 182-183).

\subsubsection{Kriz Yönetim Becerileri Ölçeğinin Güvenirlik ve Geçerlik Analizleri}

Kriz Yönetimi Becerileri Ölçeğinin 30 madde ve 3 boyutlu yapısı ile gerçekleştirilen doğrulayıcı faktör analizi sonucunda elde edilen uyum indeks değerleri Tablo 4'te gösterilmiştir. İlk DFA sonuçlarına göre 3 maddenin $(\mathrm{m} 4, \mathrm{~m} 10, \mathrm{~m} 28)$ faktör yükünün 0,40'ın altında olduğu ve model uyum indekslerinin uygun düzeylerde olmadığı tespit edildiğinden sorunlu maddeler çıkarılarak doğrulayıcı faktör analizi tekrarlanmıştır.

Tablo 4: Kriz Yönetim Becerileri Ölçeği Model Uyum Índeksleri

\begin{tabular}{|l|c|c|}
\hline Model Uyum Indeksi & 30 madde 3 boyut & 27 madde 3 boyut \\
\hline X2/sd & 3,18 & 2,60 \\
\hline RMSEA & 0,08 & 0,06 \\
\hline SRMR & 0,06 & 0,05 \\
\hline GFI & 0,80 & 0,86 \\
\hline
\end{tabular}




\begin{tabular}{|l|c|c|}
\hline Model Uyum İndeksi & 30 madde 3 boyut & 27 madde 3 boyut \\
\hline NNFI & 0,83 & 0,90 \\
\hline CFI & 0,84 & 0,91 \\
\hline $\begin{array}{l}\text { Faktör yükü } \\
\text { (min/max) }\end{array}$ & $0,28 / 0,82$ & $0,41 / 0,81$ \\
\hline $\begin{array}{l}\text { Standart hata } \\
\text { (min/max) }\end{array}$ & $0,09 / 0,11$ & $0,09 / 0,14$ \\
\hline $\begin{array}{l}\text { Faktörler arası } \\
\text { korelasyon }\end{array}$ & $0,83 / 0,85$ & $0,79 / 0,84$ \\
\hline
\end{tabular}

Ölçekten üç maddenin çıkarılıp modifikasyon önerilerine uygun kovaryans bağlantıları sonucunda model uyum indekslerinin yeterli düzeye ulaștığı, faktör yükleri ve hata varyanslarının uygun aralıklarda (Tablo 4; Şekil 1); faktör yüklerine ait t değerlerinin 0,01 düzeyinde anlamlı olduğu tespit edilmiştir (Tablo 5).

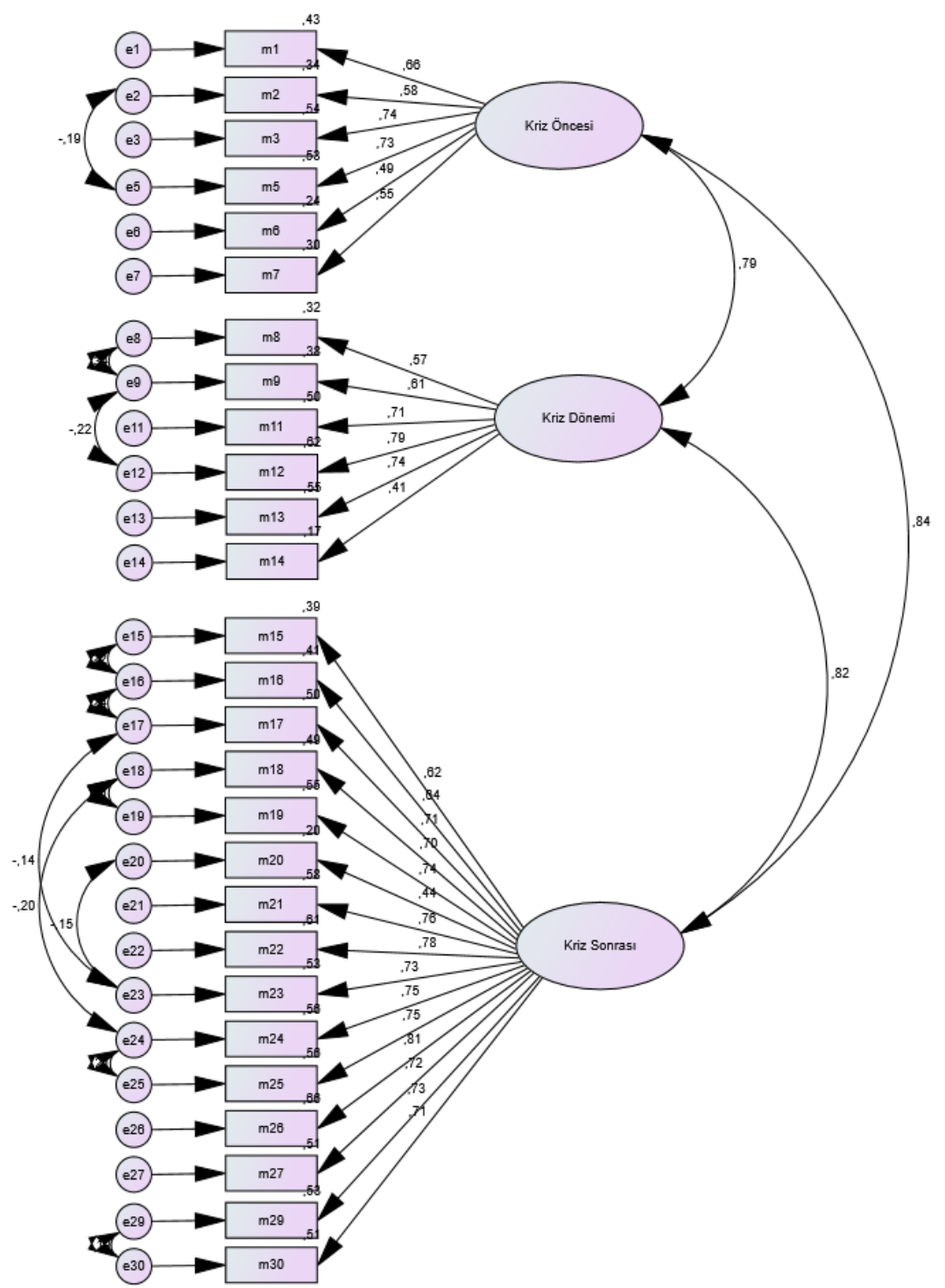

Şekil 1: Kriz Yönetim Becerileri Ölçeği DFA Diyagramı

Şekil 1'de Kriz Yönetim Becerileri DFA Diyagramında Kriz Yönetim Becerileri boyutlarının faktör yükleri bulunmaktadır. Boyutlardan Kriz Öncesi Yönetim Becerileri alt boyutuna bakıldığında "m3 - kurum için tehlike yaratabilecek sorunlar önceden saptanmaktadır" maddesi 0,74 faktör yükü ile bu boyut içerisindeki en yüksek değere sahip madde olarak 
karşımıza çıkmaktadır. Ayrıca Kriz Öncesi Yönetim Becerileri alt boyutunda yer alan "m6 - kurum kriz işaretlerine karşı duyarlıdır" maddesi 0,49 faktör yükü ile bu boyuttaki diğer maddelere göre en düşük değerli madde şeklinde gösterilebilir.

Şekil 1'de bulunan bir diğer alt boyut ise Kriz Dönemi Yönetim Becerileri alt boyutudur. Kriz Dönemi Yönetim Becerileri alt boyutunda "m12 - kurum, tüm çalışanları kriz yönetim planından haberdar etmektedir" maddesi 0,79 faktör yükü ile bu boyut içerisindeki en yüksek sayıya oluşan değer olarak ifade edilebilir. Yine bu alt boyutta bulunan "m14 kurumda tüm çalışanları kapsayacak kriz yönetimi hakkında eğitimler düzenlenmektedir" maddesi 0,41 faktör yükü ile Kriz Dönemi Yönetim Becerileri alt boyutundaki en düşük değere sahip olan madde olduğu görülmektedir.

Şekil 1'e bakıldığında üç alt boyuttan biri olan Kriz Sonrası Yönetim Becerileri alt boyutu bulunmaktadır. Bu boyutta yer alan "m26 - krizle mücadelede etkin yöntemler geliştirilmektedir" maddesi 0,81 faktör yükü boyuttaki diğer maddeler arasında en yüksek değere ulaşan madde olarak söylenebilir. Ayrıca Kriz Sonrası Yönetim Becerileri alt boyutunda bulunan "m20 - kriz sonrası kurumda durum analizi yapılmaktadır" maddesi 0,44 faktör yükü ile en düşük değerli madde olduğu anlaşılmaktadır.

Kriz yönetim becerileri ölçeği DFA ve madde analizi sonuçları Tablo 5'te yer almaktadır.

Tablo 5: Kriz Yönetim Becerileri Ölçeği DFA ve Madde Analizi Sonuçları

\begin{tabular}{|c|c|c|c|c|}
\hline Madde ve Boyut & Std. $\beta$ & $\mathbf{t}$ & $\mathbf{r}$ & $\begin{array}{c}\alpha \\
(0,94)\end{array}$ \\
\hline \multicolumn{4}{|l|}{ Kriz Öncesi Yönetim Becerileri } & \multirow{7}{*}{0,78} \\
\hline $\begin{array}{l}\text { m1. Kurum, kriz ortaya çıkmadan önce farklı kaynaklardan } \\
\text { gelen kriz sinyallerini algılayabilmektedir. }\end{array}$ & 3,13 & & 0,57 & \\
\hline m2. Kriz yaşanmadan önce kriz senaryoları oluşturulmaktadır. & 3,10 & $9,76^{\star \star}$ & 0,46 & \\
\hline m3. Kurum için tehlike yaratabilecek sorunlar önceden saptanmaktadır. & 3,26 & $12,04^{\star \star}$ & 0,65 & \\
\hline m5. Krize neden olabilecek her durum dikkatle incelenmektedir. & 3,25 & $11,85^{\star \star}$ & 0,65 & \\
\hline m6. Kurum kriz işaretlerine karşı duyarlıdır. & 3,35 & $8,52^{\star *}$ & 0,44 & \\
\hline $\begin{array}{l}\text { m7. Kurumda krizin olumsuz etkilerinden korunma } \\
\text { stratejileri konusunda bilgi sahip çalışanlar mevcuttur. }\end{array}$ & 3,14 & $9,42^{\star *}$ & 0,53 & \\
\hline \multicolumn{4}{|l|}{ Kriz Dönemi Yönetim Becerileri } & \multirow{7}{*}{0,80} \\
\hline m8. Krizden korunmak için yazılı kriz yönetim planı hazırlanmaktadır. & 3,11 & & 0,56 & \\
\hline m9. Kriz yönetim planı çerçevesinde kriz iletişim planı hazırlanmaktadır. & 3,03 & $11,21^{\star *}$ & 0,58 & \\
\hline $\begin{array}{l}\text { m11. Kurum, kriz yönetim ekibinin gerekli } \\
\text { eğitimi almasına öncülük etmektedir. }\end{array}$ & 3,03 & $10,12^{\star *}$ & 0,65 & \\
\hline $\begin{array}{l}\text { m12. Kurum, tüm çalışanları kriz yönetim } \\
\text { planından haberdar etmektedir. }\end{array}$ & 2,87 & $10,71^{\star \star}$ & 0,65 & \\
\hline $\begin{array}{l}\text { m13. Kurum çalışanlarına yaşanılan kriz hakkında } \\
\text { kesinleşmiş bilgiler verilmektedir. }\end{array}$ & 2,82 & $10,41^{\star *}$ & 0,61 & \\
\hline $\begin{array}{l}\text { m14. Kurumda tüm çalışanları kapsayacak kriz } \\
\text { yönetimi hakkında eğitimler düzenlenmektedir. }\end{array}$ & 2,97 & $6,78^{\star \star}$ & 0,40 & \\
\hline
\end{tabular}




\begin{tabular}{|c|c|c|c|c|}
\hline Madde ve Boyut & Std. $\beta$ & $\mathbf{t}$ & $\mathbf{r}$ & $\begin{array}{c}\alpha \\
(0,94)\end{array}$ \\
\hline \multicolumn{4}{|l|}{ Kriz Sonrası Yönetim Becerileri } & \multirow{16}{*}{0,94} \\
\hline $\begin{array}{l}\text { m15. Kriz yönetimi sürecinde kurum çalışanları } \\
\text { arasında işbirliği sağlanmaktadır. }\end{array}$ & 3,09 & & 0,63 & \\
\hline m16. Çalışanların karar verme sürecine katılmalarını sağlanmaktadır. & 2,88 & $12,23^{\star \star}$ & 0,64 & \\
\hline $\begin{array}{l}\text { m17. Kriz yönetim sürecinde verimli çalışmayı } \\
\text { önleyen engeller ortadan kaldırılmaktadır. }\end{array}$ & 2,99 & $11,69^{\star *}$ & 0,68 & \\
\hline m18. Kurumun amaç ve hedefleri sürekli gözden geçirilmektedir. & 3,24 & $11,65^{\star *}$ & 0,69 & \\
\hline m19. Kurum, kriz süreciyle ilgili çok yönlü değerlendirme yapmaktadır. & 3,10 & $12,12^{\star \star}$ & 0,72 & \\
\hline m20. Kriz sonrası kurumda durum analizi yapılmaktadır. & 3,27 & $7,89^{\star \star}$ & 0,42 & \\
\hline m21. Kriz sonrası kurumda yeni hedefler belirlenmektedir. & 3,22 & $12,38^{\star *}$ & 0,69 & \\
\hline $\begin{array}{l}\text { m22. Kurum, gerçekleştirilen kriz yönetimini } \\
\text { değerlendirmekte ve eksiklikleri belirlemektedir. }\end{array}$ & 3,26 & $12,63^{\star \star}$ & 0,74 & \\
\hline m23. Kurum, kriz sonrası yeni bir yapılanma çalışması yapmaktadır. & 3,22 & $12,02^{\star \star}$ & 0,67 & \\
\hline m24. Kriz sonrası kurumun vizyonu geliştirilmektedir. & 3,10 & $12,23^{\star \star}$ & 0,71 & \\
\hline m25. Kriz sonrasında kurum güçlü ve zayıf yanlarını görmektedir. & 3,28 & $12,21^{\star \star}$ & 0,70 & \\
\hline m26. Krizle mücadelede etkin yöntemler geliştirilmektedir. & 3,14 & $13,02^{\star \star}$ & 0,76 & \\
\hline $\begin{array}{l}\text { m27. Yaşanan krizler fırsata dönüştürülerek } \\
\text { kurum için yararlı hale getirilmektedir. }\end{array}$ & 2,95 & $11,85^{\star \star}$ & 0,67 & \\
\hline $\begin{array}{l}\text { m29. Olası krizle başa çıkabilmek için yeni } \\
\text { strateji ve taktikler belirlenmektedir. }\end{array}$ & 3,14 & $11,99^{\star *}$ & 0,70 & \\
\hline $\begin{array}{l}\text { m30. Çalışanlara yeni beceriler geliştirme ve } \\
\text { bunları kullanma fırsatı verilmektedir. }\end{array}$ & 2,93 & $11,78^{\star \star}$ & 0,70 & \\
\hline
\end{tabular}

Tablo 5'teki madde analizi sonuçlarına göre ölçeğin Cronbach Alpha katsayısı 0,94; alt boyutların Cronbach Alpha katsayılarının 0,78 / 0,80 ve 0,94 düzeyinde olduğu ve ölçekteki tüm maddeler için madde-toplam korelasyonunun 0,30'dan yüksek (0,40 ile 0,76 aralığında) olduğu tespit edilmiştir. Geçerlik ve güvenirlik analizleri sonuçlarına göre Kriz Yönetim Becerileri Ölçeği'nin 27 madde ve 3 boyutlu yapısı ile araştırma örneklemi için uygun, güvenilir ve geçerli bir ölçek olduğu sonucuna varılmıştır.

\subsubsection{Bulgular}

\subsubsection{Betimsel Bulgular}

Tablo 6'da katılımcıların demografik özelliklerine göre frekans ve yüzde dağılımı gösterilmiştir.

Tablo 6: Katılımcıların Demografik Özelliklerine Göre Dağılımı

\begin{tabular}{|c|c|c|c|}
\hline Demografik Değişken & Gruplar & $\mathbf{n}$ & $\%$ \\
\hline \multirow{2}{*}{ Cinsiyet } & Kadın & 126 & 33,5 \\
\hline & Erkek & 250 & 66,5 \\
\hline \multirow{4}{*}{$\begin{array}{l}\text { Yaş } \\
(39,17 \pm 9,02)\end{array}$} & 30 yaş ve altı & 73 & 19,4 \\
\hline & $31-40$ yaş & 160 & 42,6 \\
\hline & $41-50$ yaş & 100 & 26,6 \\
\hline & 51 yaş ve üstü & 43 & 11,4 \\
\hline \multirow{3}{*}{ Öğrenim düzeyi } & İlköğretim & 52 & 13,8 \\
\hline & Lise & 108 & 28,7 \\
\hline & Üniversite & 216 & 57,4 \\
\hline
\end{tabular}




\begin{tabular}{|l|l|c|c|}
\hline Demografik Değişken & Gruplar & $\mathbf{n}$ & $\mathbf{\%}$ \\
\hline \multirow{4}{*}{ Aylık gelir } & 2000TL ve altı & 71 & 18,9 \\
\cline { 2 - 4 } & 2001-3000TL & 119 & 31,6 \\
\cline { 2 - 4 } & 3001-4000TL & 87 & 23,1 \\
\cline { 2 - 4 } & 4001TL ve üstü & 99 & 26,3 \\
\hline \multirow{3}{*}{ Kurumdaki pozisyon } & Yönetici olmayan & 344 & 91,5 \\
\cline { 2 - 4 } & Yönetici & 32 & 8,5 \\
\hline \multirow{4}{*}{ Kurumdaki çalışma süresi } & 5 yıl ve daha az & 154 & 41,0 \\
\cline { 2 - 4 } & 6-10 yıl & 96 & 25,5 \\
\cline { 2 - 4 } & $11-15$ yıl & 50 & 13,3 \\
\cline { 2 - 4 } & 16 yıl ve üstü & 76 & 20,2 \\
\hline
\end{tabular}

Tablo 6’ya göre araştırmaya katılan toplam 376 büyükşehir belediye çalışanının demografik özellikleri incelendiğinde \%33,5'i kadın, \%66,5'i erkek olarak belirtilmektedir.

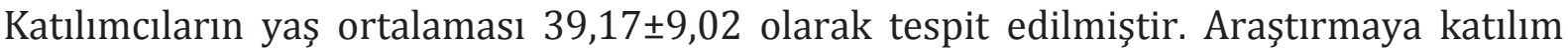
gösteren çalışanların \%19,4'ü 30 yaş ve altı, \%42,6'sı 31 - 40 yaş aralığında, \%26,6'sı 41 - 50 yaş aralığında, \%11,4'ü 51 yaş ve üstü olarak dağılım göstermektedir. Katılımcıların öğrenim durumlarına bakıldığında \%13,8'i ilköğretim, \%28,7'si lise, \%57,4'ü üniversite mezunu olarak dağılım göstermektedir. Aylık gelir durumu değerlendirildiğinde katılımcların \%18,9'u 2000 TL ve altı, \%31,6'sı 2001 - 3000 TL aralığında, \%23,1'i 3001 - 4000 TL aralığında ve \%26,3'ü ise 4001 - ve üstü şeklinde dağılım göstermektedir. Çalışanların kurumdaki pozisyonları incelendiğinde \%91,5'inin yönetici pozisyonunda olmadığı \%8,5'inin ise kurumda yönetici olarak görevini sürdürdüğü görülmektedir. Katılımcıların \%41'inin kurumdaki çalışma süresi 5 yıl ve daha az, \%25,5'inin 6-10 yıl aralığında, \%13,3'ünün 11-15 yıl aralığında, \%20,2'sinin ise 16 yıl ve üstü olarak dağılım gösterdiği anlaşılmaktadır.

Tablo 7'de ölçek ve alt boyutlarının ortalama ve standart sapma bilgilerinden oluşan betimsel istatistiklere yer verilmiştir.

Tablo 7: Ölçek ve Alt Boyutların Betimsel İstatistikleri

\begin{tabular}{|l|c|c|c|c|c|}
\hline Alt Boyutlar & $\mathbf{n}$ & Min. & Maks. & $\overline{\mathbf{X}}$ & SS \\
\hline Kriz Öncesi YB & 376 & 1,00 & 5,00 & 3,20 & 0,78 \\
\hline Kriz Dönemi YB & 376 & 1,00 & 5,00 & 2,97 & 0,77 \\
\hline Kriz Sonrası YB & 376 & 1,00 & 5,00 & 3,12 & 0,78 \\
\hline TOPLAM & 376 & 1,00 & 5,00 & 3,10 & 0,70 \\
\hline
\end{tabular}

Tablo 7'ye bakıldığında katılımcıların algısına göre kurumun kriz öncesi $(3,20 \pm 0,78)$, kriz dönemi $(2,97 \pm 0,77)$, kriz sonrası $(3,12 \pm 0,78)$ ve genel olarak kriz yönetim becerilerine $(3,10 \pm 0,70)$ ilişkin puanların "orta düzeyde" olduğu tespit edilmiştir $(5-1=4 / 5=0,80$; 1,00-1,80: "yüksek düzeyde olumsuz"; 1,81-2,60: "olumsuz"; 2,61-3,40: "ne olumlu / ne olumsuz"; 3,41-4,20: "olumlu"; 4,21-5,00: "yüksek düzeyde olumlu”). Bu doğrultuda Tablo 7 incelendiğinde kriz öncesi, kriz dönemi ve kriz sonrası yönetim becerileri arasında en yüksek değere 3,20 ile kriz öncesi yönetim becerisinin sahip olduğu görülmektedir. 2,97 değer yükü ile en düşük değerde olan alt boyut ise kriz dönemi yönetim becerisi olarak açıklanabilir.

\subsubsection{1. Ölçek Puanlarının Demografik Özelliklere Göre Karşılaştırılmasına Ait Bulgular}

Tablo 8'de kurumun kriz yönetim becerilerine ilişkin katılımcıların algı puanlarının cinsiyetine göre karşılaştırılmasına ait bağımsız iki örneklem $t$ testi sonuçlarına yer verilmiştir. 
Tablo 8: Ölçek Puanlarının Cinsiyete Göre Karșılaștırılması

\begin{tabular}{|c|c|c|c|c|c|c|}
\hline Alt Boyutlar & Cinsiyet & $\mathbf{n}$ & $\overline{\mathbf{X}}$ & SS & $\mathbf{t}$ & $\mathbf{p}$ \\
\hline \multirow{2}{*}{ Kriz Öncesi Yönetim Becerileri } & Kadın & 126 & 3,12 & 0,76 & \multirow{2}{*}{$-1,51$} & \multirow{2}{*}{0,131} \\
\hline & Erkek & 250 & 3,25 & 0,78 & & \\
\hline \multirow{2}{*}{ Kriz Dönemi Yönetim Becerileri } & Kadın & 126 & 2,81 & 0,70 & \multirow{2}{*}{$-2,85$} & \multirow{2}{*}{0,005} \\
\hline & Erkek & 250 & 3,05 & 0,79 & & \\
\hline \multirow{2}{*}{ Kriz Sonrası Yönetim Becerileri } & Kadın & 126 & 2,97 & 0,73 & \multirow{2}{*}{$-2,60$} & \multirow{2}{*}{$0,01 C$} \\
\hline & Erkek & 250 & 3,19 & 0,80 & & \\
\hline \multirow{2}{*}{ TOPLAM } & Kadın & 126 & 2,97 & 0,66 & \multirow{2}{*}{$-2,57$} & \multirow{2}{*}{0,010} \\
\hline & Erkek & 250 & 3,16 & 0,71 & & \\
\hline
\end{tabular}

Tablo 8'de kriz dönemi $(\mathrm{t}=-2,85 ; \mathrm{p}<0,05)$, kriz sonrası $(\mathrm{t}=-2,60 ; \mathrm{p}<0,05)$ ve genel olarak kriz yönetim becerilerine $(\mathrm{t}=-2,57 ; \mathrm{p}<0,05)$ ilişkin algı puanlarının katılımcıların cinsiyetine göre anlamlı farklılık gösterdiği tespit edilmiştir. Ayrıca kriz öncesi yönetim becerilerine ilişkin algı puanlarının katılımcıların cinsiyetine göre anlamlı farklılık göstermediği sonucuna da varılmıştır. Cinsiyet gruplarının bu üç alt boyuta vermiş oldukları yanıtların ortalamaları değerlendirildiğinde; kadınların ortalamaları $(\bar{X}=2,97)$ şeklinde bulunurken erkelerin ortalamaları ise $(\overline{\mathrm{X}}=3,16)$ olarak ortaya çıkmıştır. Dolayısıyla erkek katılımcıların kurumun kriz dönemi, kriz sonrası ve genel olarak kriz yönetim becerilerine ilișkin algı puanları, kadın katılımcıların algı puanlarından anlamlı düzeyde daha yüksektir. Buradan hareketle erkek çalışanlar kurumun kriz yönetim beceri düzeyini, kadın çalışanlara göre daha yüksek bulduğu anlaşılmaktadır. Tablo 8'e göre araştırmanın $\mathrm{H} 1_{\mathrm{B}}$ ve $\mathrm{H} 1_{\mathrm{C}}$ hipotezleri desteklenirken, $\mathrm{H} 1_{\mathrm{A}}$ hipotezi desteklenmemiştir.

Tablo 9'da kurumun kriz yönetim becerilerine ilişkin katılımcıların algı puanlarının katılımcıların yaş gruplarına göre karşılaştırılmasına ait ANOVA testi sonuçlarına yer verilmiştir.

Tablo 9: Ölçek Puanlarının Yaş Gruplarına Göre Karşıllaştırılması

\begin{tabular}{|c|c|c|c|c|c|c|c|}
\hline Alt Boyut & Yaş & n & $\overline{\mathbf{X}}$ & SS & $\mathbf{F}$ & $\mathbf{p}$ & Anlamlı Fark \\
\hline \multirow{4}{*}{$\begin{array}{l}\text { Kriz Öncesi } \\
\text { Yönetim Becerileri }\end{array}$} & A-30 yaş ve altı & 73 & 3,36 & 0,74 & \multirow{4}{*}{2,96} & \multirow{4}{*}{0,032} & $D>B, C$ \\
\hline & B-31-40 yaş & 160 & 3,15 & 0,79 & & & \\
\hline & C-41-50 yaş & 100 & 3,09 & 0,77 & & & \\
\hline & D-51 yaş ve üstü & 43 & 3,40 & 0,76 & & & \\
\hline \multirow{4}{*}{$\begin{array}{l}\text { Kriz Dönemi } \\
\text { Yönetim Becerileri }\end{array}$} & A-30 yaş ve altı & 73 & 3,12 & 0,75 & \multirow{4}{*}{1,32} & \multirow{4}{*}{0,266} & \\
\hline & B-31-40 yaş & 160 & 2,92 & 0,72 & & & \\
\hline & C-41-50 yaş & 100 & 2,93 & 0,81 & & & \\
\hline & D-51 yaş ve üstü & 43 & 3,02 & 0,88 & & & \\
\hline \multirow{4}{*}{$\begin{array}{l}\text { Kriz Sonrası } \\
\text { Yönetim Becerileri }\end{array}$} & A-30 yaş ve altı & 73 & 3,18 & 0,78 & \multirow{4}{*}{1,31} & \multirow{4}{*}{0,271} & \\
\hline & B-31-40 yaş & 160 & 3,10 & 0,77 & & & \\
\hline & C-41-50 yaş & 100 & 3,03 & 0,77 & & & \\
\hline & D-51 yaş ve üstü & 43 & 3,29 & 0,88 & & & \\
\hline \multirow{4}{*}{ TOPLAM } & A-30 yaş ve altı & 73 & 3,22 & 0,66 & \multirow{4}{*}{1,98} & \multirow{4}{*}{0,116} & \\
\hline & B-31-40 yaş & 160 & 3,06 & 0,69 & & & \\
\hline & C-41-50 yaş & 100 & 3,02 & 0,71 & & & \\
\hline & D-51 yaş ve üstü & 43 & 3,24 & 0,77 & & & \\
\hline
\end{tabular}

Tablo 9'a göre kriz öncesi yönetim becerilerine ilişkin algı puanlarının katılımcıların yaş gruplarına göre anlamlı farklılık gösterdiği tespit edilmiştir $(F=2,96 ; p<0,05)$. Diğer bir yandan kriz dönemi $(F=1,32 ; p>0,05)$, kriz sonrası $(F=1,31 ; p>0,05)$ ve genel kriz yönetim 
$(\mathrm{F}=1,98 ; \mathrm{p}>0,05)$ becerilerine ilişkin algı puanlarının katılımcıların yaş gruplarına göre anlamlı farklılık göstermediği tespit edilmiştir. Ortaya çıkan farkın hangi gruplar arasında olduğunu belirlemek amacıyla LSD post hoc testi yapılmıştır. Bu testin sonuçlarına göre 51 yaş ve üstü katılımcıların kriz öncesi yönetim becerilerine ilişkin algı puanları, 31-40 yaş ve 41-50 yaş grubu katılımcıların puanlarına göre anlamlı düzeyde daha yüksektir. 51 yaş ve üstü katılımcılar kurumun kriz öncesi yönetim beceri düzeyini, 31-40 yaş ve 4150 yaş grubu katılımcılara göre daha yüksek görmektedir. Bu analizin sonuçlarına göre araştırmanın $\mathrm{H} 2$ A hipotezi desteklenirken, $\mathrm{H} 2_{\mathrm{B}}$ ve $\mathrm{H} 2_{\mathrm{C}}$ hipotezleri desteklenmemiștir.

Tablo 10'da kurumun kriz yönetim becerilerine ilișkin katılımcların algı puanlarının katılımcıların öğrenim düzeyine göre karşılaştırılmasına ait ANOVA testi sonuçlarına yer verilmiştir.

Tablo 10: Ölçek Puanlarının Öğrenim Düzeyine Göre Karșılaștırılması

\begin{tabular}{|c|c|c|c|c|c|c|c|}
\hline Alt Boyut & Öğrenim Düzeyi & $\mathbf{n}$ & $\overline{\mathbf{X}}$ & SS & $\mathbf{F}$ & $\mathbf{p}$ & Anlamlı Fark \\
\hline \multirow{3}{*}{$\begin{array}{l}\text { Kriz Öncesi Yönetim } \\
\text { Becerileri }\end{array}$} & A-İlköğretim & 52 & 3,24 & 0,73 & \multirow{3}{*}{6,03} & \multirow{3}{*}{0,003} & $A, B>C$ \\
\hline & B-Lise & 108 & 3,41 & 0,72 & & & \\
\hline & C-Üniversite & 216 & 3,09 & 0,80 & & & \\
\hline \multirow{3}{*}{$\begin{array}{l}\text { Kriz Dönemi Yönetim } \\
\text { Becerileri }\end{array}$} & A-îlköğretim & 52 & 3,03 & 0,68 & \multirow{3}{*}{10,47} & \multirow{3}{*}{0,000} & $A, B>C$ \\
\hline & B-Lise & 108 & 3,23 & 0,69 & & & \\
\hline & C-Üniversite & 216 & 2,83 & 0,80 & & & \\
\hline \multirow{3}{*}{$\begin{array}{l}\text { Kriz Sonrası Yönetim } \\
\text { Becerileri }\end{array}$} & A-illköğretim & 52 & 3,22 & 0,64 & \multirow{3}{*}{11,10} & \multirow{3}{*}{0,000} & $A, B>C$ \\
\hline & B-Lise & 108 & 3,38 & 0,69 & & & \\
\hline & C-Üniversite & 216 & 2,97 & 0,82 & & & \\
\hline \multirow{3}{*}{ TOPLAM } & A-îlköğretim & 52 & 3,16 & 0,60 & \multirow{3}{*}{11,19} & \multirow{3}{*}{0,000} & $A, B>C$ \\
\hline & B-Lise & 108 & 3,34 & 0,60 & & & \\
\hline & C-Üniversite & 216 & 2,96 & 0,74 & & & \\
\hline
\end{tabular}

Tablo 10'a bakıldığında kriz öncesi $(F=6,03 ; p<0,05)$, kriz dönemi $(F=10,47 ; p<0,05)$, kriz sonrası $(F=11,10 ; p<0,05)$ ve genel olarak kriz yönetim becerilerine $(F=11,19 ; p<0,05)$ ilişkin algı puanlarının katılımcıların öğrenim düzeyine göre anlamlı farklılık gösterdiği tespit edilmiştir. Öğrenim düzeyi gruplarının bu üç alt boyuta vermiş oldukları yanıtların ortalamaları değerlendirildiğinde; ilköğretim öğrenim düzeyine sahip katılımcıların ortalamaları $(\bar{X}=3,16)$, lise öğrenim düzeyine sahip katılımcıların ortalamaları $(\bar{X}=3,34)$ üniversite öğrenim düzeyine sahip katılımclların ortalamaları $(\bar{X}=2,96)$ şeklinde belirlenmiştir. Ortaya çıkan anlamlı farkın hangi gruplar arasında olduğunu belirlemek amacıyla LSD post hoc testi yapılmıştır. Bu testin sonuçlarına göre ilköğretim ve lise düzeyinde öğrenim gören katılımcıların kurumun kriz öncesi, kriz dönemi, kriz sonrası ve genel olarak kriz yönetim becerilerine ilişkin algı puanları, üniversite düzeyinde öğrenim gören katılımcların algı puanlarından anlamlı düzeyde daha yüksektir. Dolayısıyla ilköğretim ve lise mezunu katılımcılar kurumun kriz yönetim beceri düzeyini, üniversite mezunu katılımcılara göre daha yüksek bulduğu sonucuna ulaşılabilir. Bu sonuçlara göre $\mathrm{H} 3_{\mathrm{A}}, \mathrm{H} 3_{\mathrm{B}}$ ve $\mathrm{H} 3_{\mathrm{C}}$ hipotezlerinin desteklendiği görülmektedir.

Tablo 11'de kurumun kriz yönetim becerilerine ilişkin katılımcıların algı puanlarının katılımcıların aylık gelirine göre karşılaştırılmasına ait ANOVA testi sonuçlarına yer verilmiştir. 
Tablo 11: Ölçek Puanlarının Aylık Gelire Göre Karşılaștırılması

\begin{tabular}{|c|c|c|c|c|c|c|c|}
\hline Alt Boyut & Aylık Gelir & $n$ & $\overline{\mathbf{X}}$ & SS & $\mathbf{F}$ & $\mathbf{p}$ & Anlamlı Fark \\
\hline \multirow{4}{*}{$\begin{array}{l}\text { Kriz Öncesi Yönetim } \\
\text { Becerileri }\end{array}$} & A-2000TL ve altı & 71 & 3,36 & 0,74 & \multirow{4}{*}{2,22} & \multirow{4}{*}{0,075} & \\
\hline & B-2001-3000TL & 119 & 3,25 & 0,81 & & & \\
\hline & C-3001-4000TL & 87 & 3,19 & 0,66 & & & \\
\hline & D-4001TL ve üstü & 99 & 3,05 & 0,85 & & & \\
\hline \multirow{4}{*}{$\begin{array}{l}\text { Kriz Dönemi Yönetim } \\
\text { Becerileri }\end{array}$} & A-2000TL ve altı & 71 & 3,07 & 0,72 & \multirow{4}{*}{3,79} & \multirow{4}{*}{0,011} & $A, B>D$ \\
\hline & B-2001-3000TL & 119 & 3,07 & 0,71 & & & \\
\hline & C-3001-4000TL & 87 & 3,02 & 0,70 & & & \\
\hline & D-4001TL ve üstü & 99 & 2,75 & 0,89 & & & \\
\hline \multirow{4}{*}{$\begin{array}{l}\text { Kriz Sonrası Yönetim } \\
\text { Becerileri }\end{array}$} & A-2000TL ve altı & 71 & 3,25 & 0,70 & \multirow{4}{*}{3,54} & \multirow{4}{*}{0,015} & $A, B>D$ \\
\hline & B-2001-3000TL & 119 & 3,24 & 0,79 & & & \\
\hline & C-3001-4000TL & 87 & 3,06 & 0,73 & & & \\
\hline & D-4001TL ve üstü & 99 & 2,94 & 0,86 & & & \\
\hline \multirow{4}{*}{ TOPLAM } & A-2000TL ve altı & 71 & 3,22 & 0,61 & \multirow{4}{*}{3,70} & \multirow{4}{*}{0,012} & $A, B>D$ \\
\hline & B-2001-3000TL & 119 & 3,19 & 0,69 & & & \\
\hline & C-3001-4000TL & 87 & 3,09 & 0,63 & & & \\
\hline & D-4001TL ve üstü & 99 & 2,92 & 0,80 & & & \\
\hline
\end{tabular}

Tablo 11 incelendiğinde kriz dönemi $(F=3,79 ; p<0,05)$, kriz sonrası $(F=3,54 ; p<0,05)$ ve genel olarak kriz yönetim becerilerine $(\mathrm{F}=3,70 ; \mathrm{p}<0,05)$ ilişkin algı puanlarının katılımcıların aylık gelirine göre anlamlı farklılık gösterdiği tespit edilmiştir. Ayrıca, kriz öncesi yönetim becerilerine $(F=2,22 ; p>0,05)$ ilişkin algı puanlarının katılımcıların aylık gelirine göre anlamlı farklılık göstermediği sonucuna da varılmıştır. Aylık gelir gruplarının bu üç alt boyuta vermiş oldukları toplam yanıtların ortalamaları değerlendirildiğinde; 2000 TL ve altı düzeyine sahip katılımcıların ortalamaları (X=3,22), 2001 - 3000 TL düzeyine sahip katılımcıların ortalamaları (X=3,19), 3001 - 4000 TL düzeyine sahip katılımcıların ortalamaları $(X=3,09), 4001$ TL ve üstü düzeyine sahip katılımcıların ortalamaları $(X=2,92)$ şeklinde belirlenmiştir. Ortaya çıkan anlamlı farkın hangi gruplar arasında olduğunu belirlemek amacıyla LSD post hoc testi yapılmıştır. Bu testin sonuçlarına göre aylık geliri 2000 TL ve altı ve 2001-3000TL olan katılımcıların kurumun kriz dönemi, kriz sonrası ve genel olarak kriz yönetim becerilerine ilişkin algı puanları, aylık geliri 4001TL ve üstü olan katılımcıların algı puanlarından anlamlı düzeyde daha yüksektir. Başka bir ifadeyle aylık geliri 3000TL ve altı olan kurum çalışanları kurumun kriz yönetim beceri düzeyini, aylık geliri 4001TL ve üstü olan katılımcılara göre daha yüksek bulduğu söylenilebilir. Bu sonuca göre $\mathrm{H} 4_{\mathrm{A}}$ hipotezi desteklenmezken, $\mathrm{H} 4_{\mathrm{B}}$ ve $\mathrm{H} 4_{\mathrm{C}}$ hipotezleri desteklenmiştir.

Tablo 12'de kurumun kriz yönetim becerilerine ilişkin katılımcıların algı puanlarının katılımcıların kurumdaki pozisyonuna göre karşılaştırılmasına ait bağımsız iki örneklem t testi sonuçlarına yer verilmiştir. 
Tablo 12: Ölçek Puanlarının Kurumdaki Pozisyona Göre Karșılaștırılması

\begin{tabular}{|c|c|c|c|c|c|c|}
\hline Alt Boyutlar & Kurumdaki Pozisyon & n & $\overline{\mathbf{x}}$ & SS & $\mathbf{t}$ & $\mathbf{p}$ \\
\hline \multirow{2}{*}{ Kriz Öncesi Yönetim Becerileri } & Personel & 344 & 3,18 & 0,78 & \multirow{2}{*}{$-1,74$} & \multirow{2}{*}{0,083} \\
\hline & Yönetici & 32 & 3,43 & 0,77 & & \\
\hline \multirow{2}{*}{ Kriz Dönemi Yönetim Becerileri } & Personel & 344 & 2,96 & 0,77 & \multirow{2}{*}{$-0,65$} & \multirow{2}{*}{0,515} \\
\hline & Yönetici & 32 & 3,06 & 0,84 & & \\
\hline \multirow{2}{*}{ Kriz Sonrası Yönetim Becerileri } & Personel & 344 & 3,11 & 0,78 & \multirow{2}{*}{$-1,11$} & \multirow{2}{*}{0,264} \\
\hline & Yönetici & 32 & 3,27 & 0,81 & & \\
\hline \multirow{2}{*}{ TOPLAM } & Personel & 344 & 3,08 & 0,70 & \multirow{2}{*}{$-1,30$} & \multirow{2}{*}{0,195} \\
\hline & Yönetici & 32 & 3,25 & 0,72 & & \\
\hline
\end{tabular}

Tablo 12'ye bakıldığında kriz yönetim becerilerine ilişkin algı puanlarının katılımcıların kurumdaki pozisyonuna göre anlamlı farklılık göstermediği $(p>0,05)$ tespit edilmiştir. $\mathrm{Bu}$ sonuca göre $\mathrm{H} 5_{\mathrm{A}}, \mathrm{H} 5_{\mathrm{B}}$ ve $\mathrm{H} 5_{\mathrm{C}}$ hipotezleri desteklenmemiştir.

Tablo 13.'te kurumun kriz yönetim becerilerine ilişkin katılımcıların algı puanlarının katılımcıların kurumdaki çalışma süresine göre karşılaştırılmasına ait ANOVA testi sonuçlarına yer verilmiştir.

Tablo 13: Ölçek Puanlarının Kurumdaki Çalışma Süresine Göre Karşıllaştırılması

\begin{tabular}{|c|c|c|c|c|c|c|c|}
\hline Alt Boyut & Kurumdaki Çalışma Süresi & $\mathbf{n}$ & $\overline{\mathbf{X}}$ & SS & $\mathbf{F}$ & $\mathbf{p}$ & Anlamlı Fark \\
\hline \multirow{4}{*}{$\begin{array}{l}\text { Kriz Öncesi } \\
\text { Yönetim } \\
\text { Becerileri }\end{array}$} & A-5 yıl ve daha az & 154 & 3,29 & 0,73 & \multirow{4}{*}{1,87} & \multirow{4}{*}{0,135} & \\
\hline & B-6-10 yıl & 96 & 3,14 & 0,81 & & & \\
\hline & C-11-15 yıl & 50 & 3,02 & 0,90 & & & \\
\hline & D-16 yıl ve üstü & 76 & 3,23 & 0,74 & & & \\
\hline \multirow{4}{*}{$\begin{array}{l}\text { Kriz Dönemi } \\
\text { Yönetim } \\
\text { Becerileri }\end{array}$} & A-5 yıl ve daha az & 154 & 3,06 & 0,73 & \multirow{4}{*}{1,34} & \multirow{4}{*}{0,262} & \\
\hline & B-6-10 yıl & 96 & 2,95 & 0,77 & & & \\
\hline & C-11-15 yıl & 50 & 2,83 & 0,77 & & & \\
\hline & D-16 yıl ve üstü & 76 & 2,92 & 0,85 & & & \\
\hline \multirow{4}{*}{$\begin{array}{l}\text { Kriz Sonrası } \\
\text { Yönetim } \\
\text { Becerileri }\end{array}$} & A-5 yıl ve daha az & 154 & 3,22 & 0,75 & \multirow{4}{*}{1,59} & \multirow{4}{*}{0,191} & \\
\hline & B-6-10 yıl & 96 & 3,05 & 0,80 & & & \\
\hline & C-11-15 yıl & 50 & 2,98 & 0,84 & & & \\
\hline & D-16 yıl ve üstü & 76 & 3,11 & 0,79 & & & \\
\hline \multirow{4}{*}{ TOPLAM } & A-5 yıl ve daha az & 154 & 3,19 & 0,65 & \multirow{4}{*}{1,86} & \multirow{4}{*}{0,136} & \\
\hline & B-6-10 yıl & 96 & 3,05 & 0,72 & & & \\
\hline & C-11-15 yıl & 50 & 2,94 & 0,74 & & & \\
\hline & D-16 yıl ve üstü & 76 & 3,09 & 0,74 & & & \\
\hline
\end{tabular}

Tablo 13 esas alındığında kriz yönetim becerilerine ilișkin algı puanlarının katılımcıların kurumdaki çalışma süresine göre anlamlı farklılık göstermediği $(p>0,05)$ tespit edilmiştir. Böylece $\mathrm{H6}_{\mathrm{A}}, \mathrm{H} 6_{\mathrm{B}}$ ve $\mathrm{H} 6_{\mathrm{C}}$ hipotezleri desteklenmemiştir.

Tablo 14'te ölçek boyutları arasındaki korelasyon analizi sonuçlarına yer verilmiștir.

Tablo 14: Ölçeğin Alt Boyutları Arasındaki Pearson Korelasyon Analizi Sonuçları

\begin{tabular}{|l|c|c|c|c|}
\hline Değişkenler & $\mathbf{1}$ & $\mathbf{2}$ & $\mathbf{3}$ & $\mathbf{4}$ \\
\hline 1-Kriz Öncesi Yönetim Becerileri & 1 & $0,68^{\star \star}$ & $0,72^{\star \star}$ & $0,89^{\star \star}$ \\
\hline 2-Kriz Dönemi Yönetim Becerileri & & 1 & $0,76^{\star \star}$ & $0,90^{\star \star}$ \\
\hline 3-Kriz Sonrası Yönetim Becerileri & & & 1 & $0,92^{\star \star}$ \\
\hline 4-TOPLAM & & & & 1 \\
\hline
\end{tabular}


Tablo 14 incelendiğinde, kriz öncesi yönetim becerileri ile kriz dönemi $(r=0,68 ; p<0,05)$ ve kriz sonrası $(r=0,72 ; p<0,05)$ yönetim becerileri arasında pozitif yönlü ve anlamlı bir ilişkinin tespit edildiği görülmektedir. Ayrıca kriz dönemi yönetim becerileri ile kriz sonrası yönetim becerileri arasında pozitif yönlü ve anlamlı bir ilişki söz konusudur $(\mathrm{r}=0,76 ; \mathrm{p}<0,05)$. Yukarıda yer alan analizlerin sonuçlarına göre $\mathrm{H7}$ hipotezinin desteklendiği görülmektedir.

Tablo 15'de kriz öncesi yönetim becerilerinin kriz dönemi yönetim becerileri üzerindeki etkisine ait regresyon analizi sonuçlarına yer verilmiştir.

Tablo 15: Kriz Öncesi Yönetim Becerilerinin Kriz Dönemi Yönetim Becerileri Üzerindeki Etkisine Ait Regresyon Analizi Sonuçları

\begin{tabular}{|c|c|c|c|c|c|c|}
\hline Bağımlı Değişken & Bağımsız Değişken & B & $\mathbf{S H}_{\mathrm{B}}$ & $\boldsymbol{\beta}$ & $\mathbf{t}$ & $\mathbf{p}$ \\
\hline \multirow{2}{*}{ Kriz Dönemi Yönetim Becerileri } & Sabit & 0,805 & 0,124 & & 6,499 & 0,000 \\
\hline & Kriz öncesi yönetim becerileri & 0,676 & 0,038 & 0,681 & 17,996 & 0,000 \\
\hline
\end{tabular}

Tablo 15’e göre kriz öncesi yönetim becerilerinin kriz dönemi yönetim becerileri üzerindeki etkisini gösteren modelin uygun olduğu görülmektedir $\left(F_{(1 ; 374)}=323,85\right.$; $\mathrm{p}<0,05)$. Kriz öncesi döneme ilişkin yönetim becerileri, kriz dönemindeki yönetim becerileri üzerinde pozitif yönlü ve anlaml etkiye sahip olup $(\beta=0,68 ; t=17,99 ; p<0,05)$, kriz dönemi yönetimi becerilerindeki varyansın yaklaşı \% \% ' $^{\prime} \operatorname{sinı~}\left(\Delta \mathrm{R}^{2}=0,463\right)$ açıklamaktadır. Bu bulgular doğrultusunda $\mathrm{H}_{\mathrm{A}}$ hipotezi desteklenmiştir.

Tablo 16'da kriz öncesi ve kriz dönemi yönetim becerilerinin kriz sonrası yönetim becerileri üzerindeki etkisine ait regresyon analizi sonuçlarına yer verilmiştir.

Tablo 16: Kriz Öncesi ve Kriz Dönemi Yönetim Becerilerinin Kriz Sonrası Dönem Yönetim Becerileri Üzerindeki Etkisine Ait Çoklu Regresyon Analizi Sonuçları

\begin{tabular}{|c|c|c|c|c|c|c|}
\hline Bağımlı Değişken & Bağımsız Değişken & B & SHB & $\beta$ & $\mathbf{t}$ & $\mathbf{p}$ \\
\hline \multirow{3}{*}{ Kriz Sonrası Yönetim Becerileri } & Sabit & 0,382 & 0,107 & & 3,568 & 0,000 \\
\hline & Kriz öncesi yönetim becerileri & 0,388 & 0,042 & 0,384 & 9,221 & 0,000 \\
\hline & Kriz dönemi yönetim becerileri & 0,503 & 0,042 & 0,495 & 11,881 & 0,000 \\
\hline
\end{tabular}

Tablo 16'ya bakıldığında kriz öncesi ve kriz dönemi yönetim becerilerinin kriz sonrası yönetim becerileri üzerindeki etkisini gösteren modelin uygun olduğu görülmektedir $\left(F_{(2 ; 373)}=350,27 ; p<0,05\right)$. Kriz öncesi $(\beta=0,38 ; t=9,22 ; p<0,05)$ ve kriz dönemi $(\beta=0,49$; $\mathrm{t}=11$,88; $\mathrm{p}<0,05)$ yönetim becerileri, kriz sonrası dönem ilişkin yönetim becerileri üzerinde pozitif yönlü ve anlamlı etkiye sahip olup, kriz öncesi ve kriz dönemi yönetim becerileri ile birlikte kriz sonrası yönetim becerilerindeki varyansın yaklaşık \%65'ini $\left(\Delta \mathrm{R}^{2}=0,651\right)$ açıklamaktadır. Buna göre $\mathrm{H} 8_{\mathrm{B}}$ hipotezi desteklenmiştir.

\section{Sonuç}

Çalışmada, Samsun Büyükșehir Belediyesi'nin sahip olduğu kriz yönetimi becerilerinin mevcut durumu araştırılmıştır. $\mathrm{Bu}$ araştırma ise belediye çalışanlarının tutumları göz önünde bulundurularak yapılmıştır. Kriz öncesi, kriz dönemi ve kriz sonrası yönetim becerileri alt boyutlarını kapsayan anket formu sayesinde çalışanların konu ile ilgili tutumlarına ulaşılmaya çalışılmıştır. Kriz yönetim becerilerinin alt boyutlarına ilişkin analiz sonuçları şu şekilde ifade edilmektedir: 
Kriz öncesi yönetim becerileri alt boyutu, üç boyut arasında en yüksek değer sahip boyuttur. Bu boyut kapsamında katılımcıların yeterli bulduğu konular, "kriz işaretlerine karşı duyarlı olma" ve "tehlikeleri önceden saptama" şeklinde söylenebilir. Diğer taraftan kriz öncesi yönetim becerileri alt boyutu çerçevesinde katılımclların yetersiz gördügü konular ise, "krize karşı korunma stratejileri konusunda donanımlı çalışanlara sahip olma" ve "kriz senaryoları oluşturma" olarak anlaşılmaktadır. Sonuç olarak kurum çalışanlarının algısına göre kurumun kriz öncesi yönetim becerileri alt boyutunun "orta düzeyde" olduğu tespit edilmiştir. Literatürde yer alan çalışmalara bakıldığında Özsezer (2014), liselerde çalışan yönetici ve öğretmenlerin okullarda gerçekleştirilen kriz yönetimine ilișkin görüșlerini çeșitli değișkenlere göre tespit etmiștir. Araștırmaya göre kriz yönetim becerilerine ilişkin öğretmen tutumları genel olarak orta düzeydedir. Özsezer'in (2014) yapmış olduğu çalışma bu yönü ile benzerlik gösterdiği anlaşılmaktadır.

Kriz sonrası yönetim becerileri alt boyutu, kriz yönetim becerileri alt boyutları arasında en yüksek değere sahip ikinci boyut olarak söylenebilir. Bu boyut kapsamında katılımcıların yeterli bulduğu konular, "kriz sonrası durum analizi yapma" ve "yapılan kriz yönetimini değerlendirme" şeklinde ifade edilebilir. Kriz sonrası yönetim becerileri alt boyutu çerçevesinde katılımcıların yetersiz bulduğu konular ise, "çalışanları karar verme süreçlerine dahil etme" ve "krizleri fırsata dönüştürme ve yararlı hale getirme" olarak belirtilebilir. Ayrıca kurum çalışanlarının algısına göre kurumun kriz sonrası yönetim becerileri alt boyutunun "orta düzeyde" olduğu tespit edilmiştir. Washington'da yer alan beş üniversitenin bünyesindeki kriz yönetimi planının yöneticiler tarafından nasıl oluşturulduğunu araştırmak için krizlere verilen tepkileri inceleyen Lott (2012), çalışmasında fakülte, personel ve öğrencilerin kurumdaki kriz yönetim prosedürlerine aşina olmadıklarını belirlemiştir. Ayrıca kurumun kriz meydana gelmek üzereyken cevap vermeye hazır olduğu sonucuna da ulaşmıştır. Lott'un (2012) araştırması bu yönden çalışma ile benzerlik göstermektedir.

Kriz dönemi yönetim becerileri alt boyutu, en düşük değere sahip alt boyut olarak açıklanabilir. Kriz dönemi yönetim becerileri alt boyutuna göre kurumun, çalışanlara kriz hakkında bilgi ve kriz yönetimi ile ilgili eğitim verme noktası eksikliklerinin olduğu anlaşılmaktadır. Sonuç olarak kurum çalışanlarının algısına göre kurumun kriz dönemi yönetim becerileri alt boyutunun "orta düzeyde" olduğu tespit edilmiştir. Literatürde yer alan araștırmalar irdelendiğinde Ozcan (2015) çalışmasında, olası krizleri planlama ve hazırlık, yönetim, değerlendirme aşamalarında yer alan görevleri yapmayı önleyen çeşitli engellerin bulunduğunu göstermiştir. Bu engeller ortadan kalkmadığ sürece, kamu kurumlarının krizlerle etkin bir şekilde başa çıkmasının kolay olmayacağı sonucuna ulaşmıștır. Bu yönü dikkate alındığında çalıșma ile benzer nitelikler taşımaktadır.

Kriz dönemi ve kriz sonrası yönetim becerilerine ilişkin algı puanlarının katılımcıların cinsiyetine göre anlamlı farklılık gösterdiği tespit edilmiştir. Erkek katılımcıların kriz dönemi ve kriz sonrası yönetim becerilerine yönelik algı puanları, kadın katılımcıların kriz dönemi ve kriz sonrası yönetim becerilerine ilişkin algı puanlarına göre daha yüksek düzeyde bulunmuştur. Ortaya çıkan sonucun nedeni ise, kadınların olaylara karşı bakış açılarının erkeklere göre daha geniş ölçekli olması şeklinde söylenebilir. $\mathrm{Bu}$ durum kadınların, kurumun kriz dönemi ve kriz sonrası yönetim becerilerini erkeklere göre daha gerçekçi bir biçimde yorumlamasına neden olabilir.

Kriz öncesi yönetim becerilerine ilişkin algı puanlarının katılımcıların yaş gruplarına göre anlamlı farklılık gösterdiği tespit edilmiştir. Ortaya çıkan bulgulara göre 51 yaş 
ve üstü katılımcıların kendilerinden daha düşük yaş gruplarına oranla kurumun kriz öncesi yönetim becerilerini daha yüksek düzeyde algılamasının nedeni, yaşın ilerlemesi sonucunda olaylara karşı daha olgun ve iyimser davranılması şeklinde açıklanabilir. Bu olgun ve iyimser tutum, yaşı ilerlemiş çalışanların kuruma karşı daha olumlu yaklaşmasına yol açabilir. Diğer taraftan kriz öncesi, kriz dönemi ve kriz sonrası yönetim becerilerine ilişkin algı puanlarının katılımcıların öğrenim düzeyine göre anlamlı farklılık gösterdiği tespit edilmiştir. Bu sonuca göre çalışanların eğitim seviyeleri yükseldikçe kurumdaki kriz durumuna ve kriz yönetim becerilerine olan ilgi ve farkındalığın artabileceği söylenebilir.

Gerçekleştirilen bu araştırmada kriz dönemi ve kriz sonrası yönetim becerilerine ilişkin algı puanlarının katılımcıların aylık gelirine göre anlamlı farklılık gösterdiği sonucuna varılmıştır. Analiz sonuçlarına göre aylık geliri yüksek seviyede olan katılımcıların kurumun kriz dönemi ve kriz sonrası yönetim becerilerine karşı algı puanlarının düşük seviyede olduğu belirlenmiştir. Aylık geliri düşük seviyede olan katılımcıların ise kurumun sahip olduğu kriz dönemi ve kriz sonrası yönetim becerilerine karşı algı puanlarının yüksek seviyede yer aldığı anlaşılmıştır. Ayrıca "aylık gelir" ve "öğrenim düzeyi” değişkenlerinin sonuçları incelendiğinde birbirine paralel olduğu görülmektedir. Çalışanların aylık geliri artıkça eğitim seviyeleri de artmaktadır. Bu doğrultuda eğitim seviyesi ile aylık gelirin aynı değeri taşıdığı ifade edilebilir. Sonuç olarak öğrenim ve aylık gelir düzeyi yükseldikçe kriz dönemi ve kriz sonrası yönetim becerilerine olan ilgi ve farkındalığın artabileceği söylenebilir.

Katılımcıların çalıştıkları kurumdaki kriz öncesi yönetim becerileri ile kriz dönemi ve kriz sonrası yönetim becerileri arasında pozitif yönlü ve anlamlı bir ilişki tespit edilmiştir. Diğer bir ifadeyle kriz öncesi yönetim becerilerinde verimlilik artıkça, kriz dönemi ve kriz sonrası yönetim becerilerinde de verimlilik artmaktadır. Bu doğrultuda kriz öncesinde krize karşı yapılan hazırlık faaliyetlerinin kriz dönemi ve kriz sonrasında da önem kazandığı sonucuna varılabilir.

Katılımcıların çalıştıkları kurumdaki kriz öncesi ve kriz dönemi yönetim becerileri, kriz sonrası döneme ilişkin yönetim becerileri üzerinde pozitif yönlü ve anlamlı bir etkiye sahip olduğu tespit edilmiştir. Buradan hareketle kurumun kriz öncesi ve kriz döneminde uyguladığı beceriler (kriz sinyallerini algılayabilme, kriz yönetim, iletişim ve acil eylem planlarını hazırlama, çalışanları kriz yönetim planından haberdar etme ve kriz hakkında bilgiler verme vb.), kriz sonrasında uyguladığı yönetim becerilerine (kriz sonrası durum analizi yapma, güçlü ve zayıf yönleri belirleme, olası krizle başa çıkabilmek için yeni stratejiler belirleme vb.) katkıda bulunduğu anlaşılmaktadır.

Sonuç olarak Samsun Büyükşehir Belediyesi'nin kriz yönetim becerileri "orta düzeyde" bulunmuştur. Araştırmaya katılan kurum çalışanlarının algısına göre kurumun kriz öncesi, kriz dönemi, kriz sonrası ve genel olarak kriz yönetim becerilerine ilişkin puanlarının "orta düzeyde" olduğu tespit edilmiştir. Bu doğrultuda kurumun kriz yönetim becerileri konusunda kendisini geliştirmesi ve kriz yönetimi hakkında gerekli eğitimleri alması gerekmektedir.

Kurumun bir diğer geliştirmesi gereken husus ise "çalışanlara kriz hakkında net bilgiler verme, kriz yönetimi ile ilgili eğitimler düzenleme, kriz planı hakkında bilgilendirme yapma, yeni beceriler geliştirme ve bunları kullanma fırsatı verme, çalışanların karar verme sürecine katılmalarını sağlanma" gibi konulardır. Kurum çalışanları kurumlarını bu konularda yetersiz bulmuştur. Bahsedilen konulardan da anlaşılacağı üzere ana eksiklik çalışanlara yapılması gereken faaliyetlerin yerine getirilmemesidir. Kurumun, çalışanlara 
karşı daha samimi olması, sürekli karşılıklı iletişimi sağlaması, kriz ve kriz yönetimi ile ilgili uygun eğitimler düzenlemesi gibi çalışmaları uygulamaya koyması gerekmektedir.

Son olarak kamu kurumlarının kriz yönetim becerilerini Samsun Büyükșehir Belediyesi örnekleminde belirlemeye çalışan bu araştırmanın, daha sonra yapılacak benzer araştırmalara kaynak teşkil edebileceği ve aynı zamanda diğer kamu ve özel kurumlarda kriz yönetim becerilerini belirmeye yönelik çalışmalara da kılavuzluk yapabileceği söylenebilir.

\section{Kaynakça}

Akgemci, T. (2015). Stratejik Yönetim. (4. Bs.). Ankara: Gazi Kitabevi.

Aksu, A. ve Deveci, S. (2009). İlköğretim Okulu Müdürlerinin Kriz Yönetimi Becerileri. E-Journal of New World Sciences Academy, 4(2), 448-464. Erişim adresi: https:// dergipark.org.tr/tr/download/article-file/185946

Arıkan, R. (2013). Araştırma Yöntem ve Teknikleri. (2. Bs.). Ankara: Nobel Akademik Yayıncılık.

Aydın, M. D. ve Kılınç, İ. (2004). İşletmelerde Kriz Yönetimi ve İletişimi. Ankara: Turhan Kitabevi.

Bakos, L. (2018). Crisis Management Between Public Relations and The Holonic MultiAgent Approach. Procedia - Social And Behavioral Sciences, (238), 527-534. doi:10.1016/j.sbspro.2018.04.032

Bernhardsdóttir, Á. E. (2015). Crisis-Related Decision-Making and The Influence of Culture on The Behavior of Decision Makers: Cross-Cultural Behavior in Crisis Preparedness and Response. Switzerland: Springer.

Büyükkaracığan, N. (2016). Türkiye'de Yerel Yönetimlerde Kriz ve Afet Yönetim Çalışmalarının Mevzuat Açısından Değerlendirilmesi. Selçuk Üniversitesi Sosyal ve Teknik Araştırmalar Dergisi, (12), 195-219. Erişim adresi: http://sosyoteknik. selcuk.edu.tr/sustad/article/view/95/77

Büyüköztürk, Ş. (2018). Sosyal Bilimler İçin Veri Analizi El Kitabı: İstatistik, Araştırma Deseni SPSS Uygulamaları ve Yorum. (24. Bs.). Ankara: PEGEM Akademi.

Can, H. (2005). Organizasyon ve Yönetim. (7. Bs.). Ankara: Siyasal Kitabevi.

Coombs, W. T. (2001). Teaching The Crisis Management / Communication Course. Public Relations Review, (27), 89-101. Erişim adresi: https://www.sciencedirect.com/ science/article/pii/S0363811101000728

Coombs, W. T. (2015). Ongoing Crisis Communication: Planning, Managing and Responding. (4. Bs.). London: Sage Pablications.

Çokluk, Ö., Şekercioğlu, G. ve Büyüköztürk, Ş. (2012). Sosyal Bilimler İçin Çok Değişkenli Istatistik: SPSS ve LISREL Uygulamaları. (2. Bs.). Ankara: PEGEM Akademi.

Demirtaş, H. (2000). Kriz Yönetimi. Kuram ve Uygulamada Eğitim Yönetimi, 23(23), 353373. Erişim adresi: https://dergipark.org.tr/tr/pub/kuey/issue/10 373/126950

Dinçer, Ö. (2007). Stratejik Yönetim ve İşletme Politikası. (3. Bs.). İstanbul: Alfa Yayınları.

Jaques, T. (2007). Issue Management and Crisis Management: An Integrated, Non-linear, Relational Construct. Public Relations Review, (33), 147-157. doi:10.1016/j. pubrev.2007.02.001 
Korkmazyürek, H., ve Basım, H. N. (2009). İş Modeli ve Kriz Yönetimi. Ankara: Siyasal Yayınevi.

Kotwica, K., Hayes, B. ve Correia, D. (Yay. haz.). (2013). Business Continuity: Playbook. (2. Bs.). United Kingdom: Elsevier.

Küçük, O. (2014). Bilimsel Araştırma Yöntemleri. Ankara: SAGE Matbaacılık.

Lott, M. K. (2012). Crisis Management Plans in Higher Education: Commonalities, Attributes, and Perceived Effectiveness (Doktora Tezi). ProQuest veri tabanından erişildi.

Ozcan, S. (2015). Key Factors Affecting Crisis Management Effectiveness in The Public Sector (Doktora Tezi, Southampton Üniversitesi). Erişim adresi: https://eprints.soton. ac.uk/383982/

Özdevecioğlu, M. (2002). Krizlerin İşletmelerin Yönetsel ve Örgütsel Yapısı Üzerindeki Olumsuz Etkileri ve Kayseri Sanayi İşletmelerinde Yapılan Bir Araştırma. Erciyes Üniversitesi İktisadi ve İdari Bilimler Fakültesi Dergisi, (19), 93-114. Erişim adresi: https://dergipark.org.tr/tr/pub/erciyesiibd/issue/38173/440991

Özsezer, S. (2014). Liselerde Kriz Yönetimine İlişkin Yönetici ve Öğretmen Görüşleri. (Yayımlanmamış Yüksek Lisans Tezi). Uşak Üniversitesi Sosyal Bilimler Enstitüsü, Uşak.

Patan, G. N. (2009). İşletmelerde Kriz Yönetimi ve Stratejisinin Önemi. (Yayımlanmamış Yüksek Lisans Tezi). Selçuk Üniversitesi Sosyal Bilimler Enstitüsü, Konya.

Pira, A. ve Sohodol, Ç. (2004). Kriz Yönetimi. (1. Bs.). İstanbul: İletişim Yayınları.

Sezgin, E. (2012). İşletmelerde Kriz Yönetimi ve Liderlik. (Yayımlanmamış Yüksek Lisans Tezi). Trakya Üniversitesi Sosyal Bilimler Enstitüsü, Edirne.

Şimşek, M. Ş. (1998). Yönetim ve Organizasyon. (4. Bs.). Konya: Damla Matbaacılık.

Tekin, M. ve Öztürk, A. (2010). Kriz ve Marka İletişimi. Konya: Eğitim Akademi Yayınları.

Türk Dil Kurumu (2019). Erişim adresi: https://sozluk.gov.tr/ Erişim tarihi: 17.01.2019.

Ural, A. ve Kılıç, İ. (2006). Bilimsel Araştırma Süreci ve SPSS ile Veri Analizi, (2. Bs.). Ankara: Detay Yayıncilık.

Wynne, S. A. (2009). FELE Florida Educational Leadership. Boston: XAMonline.

Yaşlıoğlu, M. M. (2017). Sosyal Bilimlerde Faktör Analizi ve Geçerlilik: Keşfedici ve Doğrulayıcı Faktör Analizlerinin Kullanılması. İstanbul Üniversitesi İşletme Fakültesi Dergisi, 46, 74-85. Erişim adresi: https://dergipark.org.tr/tr/p ub/ iuisletme/issue/32177/357061 


\title{
Crisis Management Skill of Public Institutions: A Survey on Employees of Samsun Metropolitan Municipality
}

\author{
Caner Özarslan (Ph.D. Student) \\ Ersin Diker (Asst. Prof. Dr.)
}

\section{Extended Abstract}

Nowadays, crises affect institutions and end their lives unless they are managed systematically in a planned way. In addition, these crises affect not only institutions but also their employees. It is known that the possibility of negative situations decreases thanks to result based methods applied against crises. With crisis management, it is possible to prevent crises before they occur or to resolve them after within the light of strategic methods. Besides, it can be said that the crisis management skills of the institution can help the solution of existing crisis.

Crises can be stated as depression that do not remain in the local area with the effect they have, but have the feature of reaching the universal dimension. Both private and public institutions get in crises with different types of impact. Public institutions that benefit the society do their own management by implementing various strategies and plans for the crises. This management either benefits the public institutions or causes negative results. At this point, the subject of the study can be stated as an analysis of the current situation of the crisis management skills of Samsun Metropolitan Municipality which is a public institution.

In this study, it is aimed to determine the current situation of the crisis management skills of Samsun Metropolitan Municipality by taking into consideration the attitudes of the employees. Within the direction of this aim, the level of crisis management skills of the institution is revealed with the questionnaire applied to the institution selected as the sample. The importance of the research can be expressed both as a contribution to the literature in this field and as a new approach to the activities that the institutions will implement in crisis management. Institutions by considering this research, the study may benefit the crisis management activities to be carried out before, during and after the crisis. In addition, no study has been reached in the sample of the Samsun Metropolitan Municipality demonstrating the current status of crisis management skills. With this aspect, it is expected to contribute to the literature and new researches. On the other hand, due to time constraints and financial difficulties, not all employees could be reached in the study limited in the sample of Samsun Metropolitan Municipality. For this reason, simple random sampling method has been preferred and 406 participants have been selected.

One of the quantitative research methods accepted in the field of social sciences is found to be suitable for the method of the study and the data have been analysed with confirmatory factor analysis, two independent samples test, Anova, correlation and regression analysis. As of November 2018, 2713 employees are employed in Samsun Metropolitan Municipality. This number has been determined by the authorized personnel working in the municipality. Therefore, the scope of the research which shows the current status of the crisis management skills of the municipality is composed of 2713 employees in the institution. Considering the number, 406 employees working in Samsun Metropolitan 
Municipality constitute the sample of the study. In this respect, the questionnaire, which has proven validity and reliability to the employees of the company, was conducted in November 2018 within the framework of simple random sampling method. Within the determined sample number, 406 corporate employees have participated in the survey application based on voluntariness. Of the 406 surveys, 30 have been deemed invalid for significant reasons and 376 surveys have been conducted. Prior to the survey application, pre-test has been conducted for the personnel of the institution. 51 corporate employees have participated in the pre-test. As a result of this study, the incomprehensible parts of the questionnaire have been corrected and the questionnaire has been redesigned. In addition, after the pre-test, 6 trap questions have been created in the survey and the level of participation of the employees in the survey has been tried to be understood. For these trap questions, reverse coding has been performed during data entry.

Findings have been evaluated by analysing the data obtained from the survey application. As a result of the study, it is understood that the institution is insufficient in activities such as being more sincere to employees, providing continuous mutual communication, and organizing appropriate trainings related to crisis and crisis management. On the other hand, the significant difference between the perception scores of the institution's crisis management skills according to the gender of the participants has occurred only in the sub-dimensions of the crisis period and post-crisis management skills. Male participants' perception scores of crisis and post-crisis management skills have been higher than female participants' perception scores of crisis and post-crisis management skills. The reason for the result can be said to be that women's point of view to events is broader than men. This situation may cause that women can interpret the institution's crisis and post-crisis management skills more realistically than men. In addition, it is found that the perception scores of the institution's general crisis management skills differed significantly according to the education level of the participants. According to this result, it can be said that as the education level of the employees increases, the interest and awareness of the crisis situation and crisis management skills in the institution may increase. On the other hand, a positive and significant relationship has been found between the pre-crisis management skills and the crisis and post-crisis management skills of the participants. In other words, as productivity increases in pre-crisis management skills, it increases in crisis period and post-crisis management skills as well. In this respect, it is understood that the pre-crisis management skills put forward by the Samsun Metropolitan Municipality during crisis processes are solution and result based and have a positive effect on the crisis period and post-crisis management skills. It can be concluded that the preparatory activities against the crisis before the crisis has gained importance during and after the crisis as well. When the general result of the study is examined, it is seen that the current crisis management skills of the institution are "moderate".

Keywords: Crisis, Crisis Management, Crisis Management Skills, Public Institution, Samsun Metropolitan Municipality. 